\title{
PRAHA TŘICÁTÝCH LET 20. STOLETÍ OČIMA ŠESTNÁCTILETÉ FRANCOUZKY*
}

\author{
Jaroslava Kašparová (Praha)
}

\section{Prague in the 1930s through the Eyes of a 16-Year-Old French Girl}

\begin{abstract}
An interesting item of Bohemian provenance has been preserved in the archives of the Institut d'études slaves (IES) in Paris, namely in the André Mazon collection, which comprises, among other things, the correspondence of the Mazon family. It is a set of 12 letters sent by a young student, Jacqueline Mazon, daughter of the famous French Slavist André Mazon, to her mother, Jeanne Roche-Mazon, from Paris and Prague. They concern her stay in Prague from the end of August until the middle of October 1934, when the girl lived in the family of the Prague businessman Otakar Podhajský in Hostivař in the company of his daughters of approximately the same age. The correspondence provides insight not only into the personal experiences and feelings of a French teenager living in a culturally different environment and absorbing its language and culture or into the lives of the French intellectual family of the Mazons and the Czech business family of the Podhajskýs, but especially into the lives of the Prague city burghers in the middle of the 1930s. It presents an interesting image of Prague and its inhabitants, artistic monuments as well as cultural and economic situation at that time, an image captured through the eyes of a foreigner, the future Bohemist, which Jacqueline Mazon remained until the end of her life. The article is thus one of the contributions to the history of French-Czech cultural relations of the first half of the 20th century.
\end{abstract}

Keywords: Institut d'études slaves Paris (IES) - collection of André Mazon (1881-1967) - correspondence of Jeanne Roche-Mazon (1885-1953) - letters of Jacqueline Mazon (1918-2008) - September 1934 - language stay - family of the businessman Otakar Podhajský (1876-1940) - Prague from the perspective of a French teenager - contemporary witness

Úvod

S potěšením konstatujeme, že po dlouhém období, kdy měla česká badatelská veřejnost z politických důvodů jen omezené možnosti tématiku česko-francouzské vzájemnosti rozvíjet, nastalo jak ve Francii, tak v České republice na sklonku osmdesátých let minulého století období intenzívního badatelského studia založeného na bohatě dochovaném pramenném materiálu. Díky vzájemné spolupráci a četným vzájemným kontaktům francouzských a českých badatelů ${ }^{1}$ dochází $\mathrm{k}$ renesanci a oživení tradiční česko-francouzské spolupráce v oblasti kultury a vědy. Vzniká celá řada prací, monografií, samostatných článků, zorganizována byla řada uměleckých výstav i odborných česko-francouzských seminářů, at' v České republice nebo ve Francii. Významnou roli v tom hrají nejen kulturní instituce, které mají rozvoj česko-francouzské spolupráce ve své náplni (pařǐžský Institut d'études slaves, České centrum v Paříži, Francouzský institut a Centre français de recherche en sciences sociales v Praze aj.), ale také univerzitní a školská pracoviště (Sorbonna, INALCO, Karlova univerzita, Palackého univerzita, Jihočeská univerzita aj.), v neposlední řadě pak i výukové a zájmové kulturní organizace (např. obnovené české Alliance française) a knihovní, archivní či muzejní instituce obou zemí. Francouzskočeská spolupráce mající podporu př́slušných ministerstev kultury a školství se pozitivně projevuje i v tom, že vzniká celá řada společných badatelských projektů, které mapují nejen starší, ale i nedávnou historii vzájemných politických, hospodářských a kulturních česko-francouzských a francouzsko-českých vztahů.

Francouzská i česká odborná veřejnost si je vědoma toho, že bohaté archivní a knižní fondy Institutu d'études slaves v Paříži (IES, čes. Institut slovanských studií), v němž se mj. nacházejí díky okolnostem jeho vzniku a historickému vývoji četné doposud neprobádané slavistické a bohemikální dokumenty představující studnici pramenů $\mathrm{k}$ francouzsko-českým vztahům a francouzsko-české vzájemnosti. Před několika lety proto zahájil jejich postupné vědecké zpracování

\footnotetext{
* Text př́spěvku je jedním z výstupů projektu Virtuální rekonstrukce rozptýlených provenienčně bohemikálních knižních celků v tuzemských i zahraničnich knihovnách (DG18P02OVV009) financovaného Ministerstvem kultury ČR v rámci Programu na podporu aplikovaného výzkumu a experimentálního vývoje národní a kulturní identity (NAKI II).

Pomineme-li oblast současné překladové literární tvorby, připomeňme si alespoň některá známá jména francouzských a českých badatelů zabývajících se česko-francouzskou tématikou daného či staršího období: z francouzských bohemistů jsou to zejm. historikové Hana Voisine-Jechová, Antoine Marès, Marie-Elisabeth Ducreux, Bernard Michel, Jean-Philippe Namont, literární historikové Xavier Galmiche, Catherine Servant nebo umělecká historička Markéta Theinhardt, z českých badatelů se česko-francouzskými vztahy dlouhodobě zabývali či zabývají, např. Pavla Horská, Milena Lenderová, Stéphane Reznikow, Claire Mádlová, Jitka Radimská, Jiří Hnilica, Jan Zatloukal, Martin Kučera, Doubravka Olšáková, Tomáš Chrobák, Miloš Zelenka, Zuzana Raková, Anna Pravdová a řada dalších. Pokud jde o archivní prameny a bohatou literaturu k francouzsko-českým vztahům, lze odkázat zejm. na dizertační práci J. Hnilici (HNILICA 2012) a další jeho četné práce.
} 
formou digitalizace jednotlivých fondů a jejich následné zpř́stupňování široké badatelské veřejnosti. ${ }^{2}$ Čeští badatelé se dle svých možností tohoto zpř́stupňování účastní - konkrétně olomoucká fakulta Univerzity Palackého ${ }^{3} \mathrm{a} v$ rámci projektu „PROVENIO“ také Knihovna Národního muzea. ${ }^{4}$ Rešitelé tohoto projektu se ve spolupráci s francouzskou stranou snaží v mezích možností přispět k poznání a rehabilitaci některých písemných svědků česko-francouzské vzájemnosti, které se v Institutu dochovaly. A platí to pochopitelně i obráceně; rovněž v našich institucích, knihovnách, archivech i muzeích, se ukrývají cenné česko-francouzské materiály, jež mohou bohemikální dokumenty archivu Institutu slovanských studií doplnit a obohatit. Platí to např. o archivních materiálech vztahujících se $\mathrm{k}$ francouzskému slavistovi a bohemistovi André Mazonovi (1881-1967). ${ }^{5}$ Osobní pozůstalost tohoto významného bohemisty a rusisty je uložena právě v Institutu d'études slaves, který jako ředitel v letech 1937-1959 vedl a rozvíjel. V současné době je těmto archivním materiálům věnována velká pozornost jak ze strany samotných pracovníků Institutu, tak ze strany francouzské i zahraniční odborné veřejnosti. Osobnost André Mazona, který studoval mj. i na Karlově univerzitě v Praze a navázal zde četné profesní a přátelské kontakty, ${ }^{6}$ je typickým př́kladem vědce mezinárodního přesahu, a proto nepřekvapí, že cenné informační zdroje $\mathrm{k}$ jeho biografii a dílu lze pochopitelně nalézt i v českých institucích.?

Předkládaný článek je jedním z mnoha materiálových příspěvků vztahujícím se k problematice česko-francouzských kulturních vztahů první poloviny 20. století a dalším z výsledků bohemikálního archivního bádání pracovníků Knihovny Národního muzea v pařížském v Institutu d'études slaves v roce 2019. Tematicky navazuje na článek uveřejněný v časopise Acta Musei Nationalis Pragae - Historia litterarum v roce 2020. ${ }^{8} \mathrm{~V}$ archivním fondu André Mazon se dochovaly mj. i četné archiválie týkající se rodiny André Mazona: především jeho ženy Jeanne Roche-Mazonové (1885-1953) a dcery Jacqueline Mazonové (1918-2008). ${ }^{10}$ V korespondenci Jeanne Roche-Mazonové nás zaujaly dopisy, které jí dcera Jacqueline posílala do Francie v září 1934 ze svého pobytu v Praze. ${ }^{11}$ Jedná se o prrijatou korespondenci (odeslaná korespondence, tj. dopisy, které v tu dobu matka posílala Jacqueline do Prahy, ve složce bohužel chybí).

$\mathrm{V}$ prvé části článku jsme se rozhodli obsah dopisů Jacqueline Mazonové přiblížit české badatelské veřejnosti nikoliv v plné edici či v obrazovém zveřejnění fotokopií francouzského textu doplněného doslovným českým překladem, ale formou komentované analýzy. Cílem našeho př́spěvku tedy není kritická edice a ani doslovný přepis francouzského textu s paralelním českým překladem. A to jednak kvůli případnému neúnosně dlouhému rozsahu článku a jednak kvůli některým nepřiliš zajímavým nebo opakujícím se textovým pasážím dopisů; v neposlední řadě i formálním nedostatkům dochované korespondence. Rozboru jsme podrobili devět „pražských“ dopisů šestnáctileté Francouzky z časového rozmezí od 3. září do 27. záŕí 1934, k nimž jsme přiřadili ještě tři dopisy z Paříže (dva psané před cestou do Prahy, a to 29. a 31. srpna, a třetí z 15 . října napsaný po návratu). Dopisy jsou psané na papíru o velikosti A5, nepř́lliš pečlivě, text je místy špatně čitelný (škrtán nebo opravován či doplňován). Líčení osobních zážitků je značně neformální až poněkud neuspořádané a „,neučesané“; pisatelka tzv. „skáče z jednoho tématu na druhý“, a to často i nepř́liš logicky

\footnotetext{
2 Viz zejm. projekt NUMERISLAV, elektronický portál pařížského Institut d'études slaves sloužící k zpřístupnění digitalizovaných obrazových a textových materiálů z fondů pař́žských archivů (na prvém místě samotného Institutu) v oboru slavistiky za období 1920-1960. V roce 2020 se stal součástí velkého souborného portálu dalších 15 databází humanitních věd (Humanité Numériques) přinášející digitální data a nové poznatky bádání z různých humanitních věd v regionu (oblasti Région Île-de-France): DIM (Domaine d’Intêret Majeur) „Sciences du texte et connaissances nouvelles“. Hlavním garantem projektu NUMERISLAV je Institut d'études slaves a výzkumné centrum filozofické fakulty pařížské Sorbonny „Cultures et sociétés d'Europe orientale, balkanique et médiane - EUR'ORBEM“ ve spolupráci s francouzskými i zahraničními bohemisty a rusisty (bliže viz NUMERISLAV). Viz též soubor studií věnovaný André Mazonovi v Revue d'études slaves v roce 2011 (RES 2011 ) a studie věnované Institutu slovanských studií v Paříži v Revue d'études slaves z roku 2020 (RES 2020).

3 Odborný pracovník katedry romanistiky olomoucké univerzity Jan Zatloukal zabývající se osobností a dílem Jana Čepa spolupracuje s pařížským Institutem dlouhodobě; zpracovává archivní materiál týkající se Vladimíra Pešky (1920-2002) literárního vědce, slavisty a knihovníka Institutu. K tomu více ROMANISTIKA UP a ZATLOUKAL 2009, ZATLOUKAL 2014 a ZATLOUKAL 2016.

Francouzsko-českých kulturním vztahům se věnuje dlouhodobě také olomoucký romanista Martin Kučera, který připravuje k nadcházejícímu 110. výročí založení první moravské sekce Alliance française v Olomouci výstavu a publikaci (viz KUČERA RKP 2020) a jeho autorský a redaktorský podíl na vzniku zvláštního čísla olomouckého kulturního časopisu Krok věnovanému Francouzům na Olomoucku, zejm. jeho prŕspěvek Projevy frankofilství na Hané v první polovině 20. století, srov. KROK 2020, s. 3-7 aj.).

4 Viz KAŠPAROVÁ-MĚŘIČKA 2019 a KAŠPAROVÁ 2020.

${ }^{5}$ K André Mazonovi srov. např. VAILLANT 1969, VEYRENC 1985, s. 260-262, CHROBÁK 2007 a MARÈS 2011 a BREUILLARD 2011. Viz též PROVENIO DATABÁZE https://provenio.net/records/4d40646c-88f3-4c95-9cle-e41c3172290b, kde je uvedena další literatura $\mathrm{k}$ jeho osobě.

${ }^{6}$ Mazon v roce 1919 prožil několik měsíců na doporučení svého učitele Louise Eisenmanna v Praze jako tlumočník generála Maurice Pellého, který stál v čele oficiální vojenské mise podílející se na vytvoření nového československého generálního štábu - viz NOSKOVÁ 2020 , s. 101.

7 V Literárním archivu Památníku národního písemnictví se nachází dopisy, které svým českým přátelům psal (v osobní pozůstalosti Hanuše Jelínka, Čeňka Zíbrta, Jiř́ího Polívky, Františka Pastrnka, Arne Nováka, Otokara Fischera, Jana Mukařovského aj.). Korespondence André Mazona a Jacqueline Mazonové je uložena rovněž v osobním fondu Jiřího Horáka a Lubora Niederleho v Masarykově ústavu AV ČR-Archiv Ústavu T.G.M.

${ }^{8}$ Viz KAŠPAROVÁ 2020. V osobním fondu Václava Tilleho uloženém v Literárním archivu Památníku národního písemnictví se pak dochovaly archiválie týkajíć́ se Jeanne Roche-Mazonové.

9 ARCHIVES IES MAZONOVÁ. K osobě Jeanne Roche-Mazonové viz PROVENIO DATABÁZE: https://provenio.net/records/ddfdd01e-679f$460 c-b 3 d 6-f 8 e d 76 b 250 c 4$, kde je též další literatura.

${ }^{10}$ O Jacqueline Mazonové podrobněji viz KAŠPAROVÁ 2020, s. 16-19 (III. Dcera slavného otce); zde uvedena ještě s nejistým datem narození 1917). K Jacqueline Mazonové viz též PROVENIO DATABÁZE http://provenio.net/authorities/58581 (rozkolísaný údaj o narození ca 1917-1918 již definitivně upraven na rok 1918).

${ }^{11}$ Kde je uložen osobní pozůstalostní fond Jacqueline Mazonové, nám není známo. Jisté je, že archivní fond André Mazon jej neobsahuje (přestože knižní pozůstalost nese společné exlibris otce a dcery, André a Jacqueline Mazonových, a mnohé knihy, jež patřily Jacqueline, jsou ve fondu knihovny Institutu dochovány; vedle průběžných knižních darů uskutečněných již za života majitelky).
} 


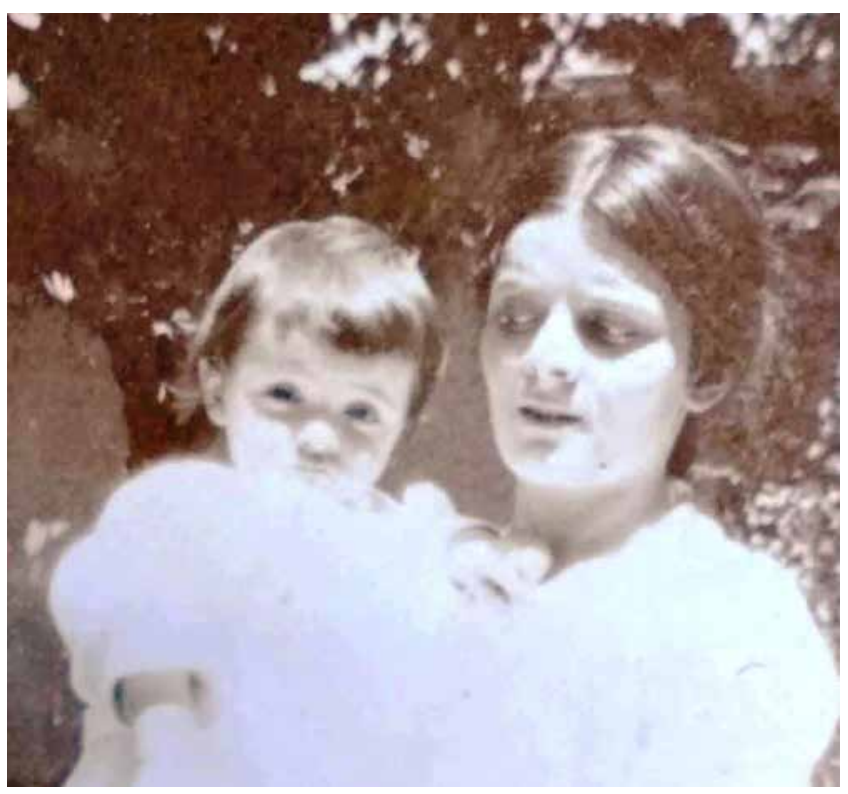

Obr. 1. Jeanne Roche-Mazonová s malou Jacqueline (fond Mazon, archiv Institutu slovanských studií v Pařízii).

a nečekaně. Někdy se popis událostí a jejich hodnocení variantně opakuje, nebot' dívka se v něm snaží držet časovou posloupnost jednotlivých událostí (bylo, bude), a to zejména když píše s časovým zpožděním. Písmo je mnohdy nedbalé a prozrazuje, že pisatelka dopisy psala ve chvatu. A to bud' proto, že spěchala $\mathrm{s}$ dopisem na poštu $\mathrm{v}$ předem stanovený den a hodinu, aby nedocházelo ve vzájemné korespondenci s matkou k prodlevě, nebo prostě proto, že na psaní jí vzhledem k jiným aktivitám nezbývalo mnoho času (Jacqueline nechce psaním zdržovat své české kamarádky, které mají za úkol se jí věnovat). Pisatelka si je spěchu i stylistických nedostatků vědoma. $\mathrm{V}$ dopise $\mathrm{z} 15$. zárí se např. omlouvá: „Píšu ti rychle a zdá se mi, že nedodržuju pokaždé větný slovosled "12, v dopise z 24. t. m. můžeme číst tuto omluvu: „Promiň mi tento prapodivný dopis, celý zmatený - chtěla bych, aby odešel nejdřiv jak to jen bude možné. "13 Na několika místech je text silně škrtán, někde je naopak dodatečně vpisován. Ani fyzický stav dopisů není ideální; svoji roli v tom sehrál patrně použitý papír, stejně jako skutečnost, že dopisy mohly být čteny víckrát (patrně nejen osobou, které byly určeny), anebo že dopisy byly po přečtení uchovávány jinak než ostatní písemné dokumenty apod. V úvodu této první části věnujeme nejdříve bližší pozornost rodině Podhajských, u nichž Jacqueline $\mathrm{v}$ Praze pobývala (a to z důvodu lepšího pochopení popisovaných událostí i prostředí, v němž se Francouzka ocitla) a poté podle časové posloupnosti přetlumočíme obsah jednotlivých dopisů, které doplníme citáty z nich (v českém překladu i originále), popř. vysvětlujícím či doplňujícím komentářem. ${ }^{14}$
Ve druhé části příspěvku se pokusíme shrnout témata, jichž se pisatelka ve svých dopisech dotýká. A to jak ve vztahu k její osobě a osobám, o nichž se dívka zmiňuje, tak také k pražským reáliím, v nichž se pohybovala a kterých si všímala. Domníváme se, že takto lépe vyniknou pisatelčiny dojmy a zážitky, mnohdy subjektivní, jinde překvapivě objektivní, a bude možno si učinit ucelenou představu o tom, jakýma očima pisatelka viděla danou realitu a jaký obraz si o Praze a Pražanech vytvořila. Ten nepochybně formoval v následujících letech její vztah k české kultuře, českému jazyku a literatuře i českému národu.

V závěru práce se pokusíme o zhodnocení významu rozebírané korespondence $\mathrm{v}$ kontextu dobového kulturního transferu, pohledu očima „toho druhého“. A to jak vzhledem $\mathrm{k}$ pisatelce a zainteresovaným osobám, jimž je adresována nebo jichž se týká, tak vzhledem ke kulturně jazykové realitě, ve které vznikla i do které byla zasílána.

\section{Jacquelinin pražský pobyt}

Jacqueline Mazonová odjela do Čech s otcem André Mazonem, uznávaným lingvistou a slavistou, který jel pracovně do Prahy a posléze do Polska (účastnil se ve dnech 23.-30. září 1934 II. Mezinárodního sjezdu slavistů, který se konal ve Varšavě a Krakově). ${ }^{15}$ Mazon strávil v době svých raných studií v Praze jistý čas a v Československu, kam se př́ležitostně vracel, měl tedy nejen řadu profesních kontaktů a zájmů, ale také řadu známých a přátel. Dospívající dceru, která měla prázdniny, vzal při této příležitosti s sebou. Chtěl jí tímto pobytem umožnit poznat Prahu a české prostředí zblízka a posílit její znalost češtiny, ${ }^{16}$ a to zejména $\mathrm{v}$ kontaktu s rodilými mluvčími stejně starými. Do Prahy odjeli společně vlakem v sobotu 1. záríi a v neděli 2. zář́ 1934 byli již na místě. Bydleli každý zvlášt' André Mazon v luxusním hotelu Paříž na Starém Městě, Jacqueline v Hostivaři, v rodině Ing. Otakara Podhajského (1846-1940) a jeho manželky Anny Podhajské, rozené Steyskalové (1881-1949).

I když některé procházky po Praze či návštěvy divadla absolvovali otec a dcera spolu, společnost Jacqueline dělala většinou rodina Podhajských, zejména jejich dcery, přibližně staré jako Jacqueline, nebo sestra pana Podhajského slečna Klementina Anna Rosalie Podhajská, zvaná „teta Klemi“ (1878-1974). Pražský pobyt mladé dívky byl sice naplánován a zorganizován otcem, ten však své dospívající dceři dopřál jistou volnost a samostatnost při poznávání Prahy a pražského prostředí, což byl, jak se lze domnívat, zjevně určitý záměr ze strany rodičů. André Mazon se po skončení sjezdu slavistů vracel 30. záŕí z Krakova do Pař́že sice přes Prahu, ale odjížděl sám vlakem v úterý 2. rríjna (v Paříži byl následujícího dne - 3. ř́ina 1934). Jacqueline odjížděla

${ }^{12}$ „Je t'écris vite et il me semble que je ne respecte pas toujours la syntaxe. “

13 „Pardon de cette lettre abracadabrante et tout en désordre - je voudrais qu'elle parte le plus tôt possible. “

${ }^{14}$ Fotografie pořízené v roce 2019 mají dokumentační charakter, následné kvalitní fotokopie (a to alespoň té lépe dochované části korespondence) se nám už bohužel nepodařilo pořídit, tak, jak jsme to měli v plánu (naše návštěva pařížského archivu v roce 2020 se z důvodu COVID pandemie neuskutečnila).

${ }^{15}$ Sjezd slavistů končil v Krakově 30. záŕí.

${ }^{16}$ Jacqueline měla díky svému otci, který uměl česky velmi dobře, už solidní znalosti češtiny z domova (navíc se traduje se, že byla po jistou dobu vychovávána českou chůvou a český jazyk tak přirozeně vstřebávala jako malá, viz KAŠPAROVÁ 2020, s. 17, pozn. 86). 




Obr. 2. Obálka českého překladu pohádky Jeanne-Roche Mazonové O polovičním kohoutovi s ilustracemi Zd. Seydla v edici Korálky (Praha 1962).

z Prahy také sama, vlakem o den dříve, v pondělí 1. ř́jja (do pařížského bytu Mazonových dorazila 2. října 1924).

\section{Pražská rodina Podhajských}

Rodina Podhajských patřila v té době k vyšší společenské třídě. Ing. Otakar Podhajský ${ }^{17}$ byl jeden z nejvýznamnějších českých průmyslníků a strojírenských podnikatelů první republiky (od roku 1926 vystupovala jeho firma jako akciová společnost s kapitálem 3,5 mil. Kč), ${ }^{18}$ zakládající člen České

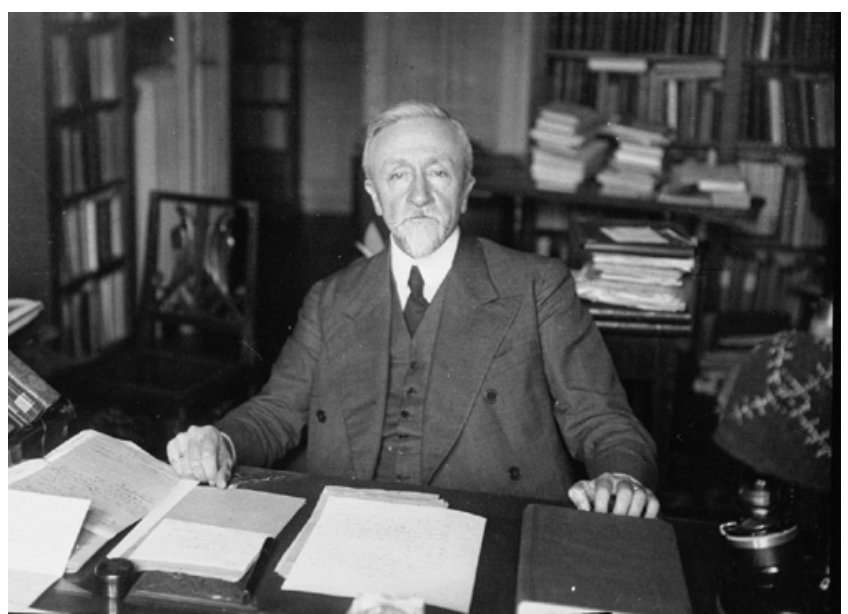

Obr. 3. André Mazon v roce 1934 (Gallica, BN de France).

Matice technické. ${ }^{19}$ Pocházel ze středních sociálních vrstev vyrůstal v rodině okresního školního inspektora Vincence Podhajského (1840-1918), nejprve v Poličce, Rychnově nad Kněžnou a od roku 1894 v Praze. Po vystudování gymnázia vzhledem k tomu, že se u něho již v mládí projevovala výrazná záliba v technických věcech, absolvoval studia na strojní fakultě české a německé techniky v Praze. Po složení státní zkoušky odjel na studijní pobyt do Německa (Mnichov, Düsseldorf) a Belgie (Lutych) a cenné studijní a pracovní zkušenosti získal také v USA, kde pobýval a pracoval v letech 1904-1909.

Po návratu do Prahy vstoupil jako společník do firmy Janka v Radotíně zabývající se výrobou ventilátorů. V roce 1912 se osamostatnil a $\mathrm{v}$ následujícím roce si v Hostivaři založil za finanční pomoci rodiny, zejména bratra Jaroslava, který byl jeho společníkem, ${ }^{20}$ vlastní továrnu vyrábějící větrací techniku a ocelový kancelářský nábytek (stoly, skř́ině, regály, zásuvky, registratury apod.), později zaměřenou především na výrobu obráběcích strojů, jež přispěla k prosperitě i světové proslulosti podniku. ${ }^{21}$

Strojírna Ing. Otakar Podhajský (pozdější TOS Hostivař), ${ }^{22}$ dnes neexistující průmyslový areál v jižní části ulice U Pekáren, vznikla jako první tovární objekt v hostivařské průmyslové zóně (vyprojektoval jej známý pražský architekt Bohumil Hypšman, který je rovněž autorem projektu obytných domů pro zaměstnance, které nechal Podhajský postavit pro svou továrnu, a prvního hostivařského kina

\footnotetext{
${ }^{17}$ Odborná literatura uvádí jeho jméno též v podobě Podhájský.

${ }^{18}$ Viz HOŘEJŠ 2005b, s. 103-121, HOŘEJŠ 2006 a DRVOTA 2012. K osobě O. Podhajského a jeho podnikání viz též osobní fond Podhajského zetě, Jana Schieszla-Podhajského (1908-1999), který po sňatku s jeho dcerou Helenou přijal jméno svého tchána, viz BADATELNA EU: Archiv Národního technického muzea, fond 731, Schieszl - Podhajský Jan, Ing. Materiály z let 1894-1987. Dostupné z: http://pametoveinstituceonline. cz/fond/164442/. Fond je bohužel zatím nezpracován.

${ }^{19}$ Srov. VELFLÍK 1906 („,chef-inženýr Podhájský Otakar“).

${ }^{20}$ Jaroslav Podhajský (1884-1973) se po roce 1945 podílel na vrácení českých strojů za války vyvezených do Německa, ale dostal upozornění, že by se neměl do Československa vracet. Takže se i s rodinou v roce 1950 vystěhoval do Brazílie, kde také žil a zemřel (podle vzpomínek pravnuka Jana Patery). K tomu srov. GOLIS 2018.

${ }^{21}$ Mezi nejvýznamnější zakázky patřila vzduchotechnika pro hrobku českých králů v kryptě chrámu Svatého Víta a strojový archiv pro Ústřední sociální pojišt'ovnu postavenou v Křížové ulici na Smíchově v letech 1935-1936 (unikátní zařízení kartotéky, které sloužilo až do roku 2002, je dnes chráněno jako kulturní památka České republiky - viz KONÁRKOVÁ 2013).

${ }^{22} \mathrm{Ke}$ staré Hostivaři, průmyslové zóně i historickým památkám srov. MÍSTOPIS-HOSTIVAŘ. K historii výroby obráběcích strojů továrny Podhajského, TOS Hostivař aj. viz HOŘEJŠ 2005a, HOŘEJŠ 2005b, HOŘEJŠ 2006.
} 


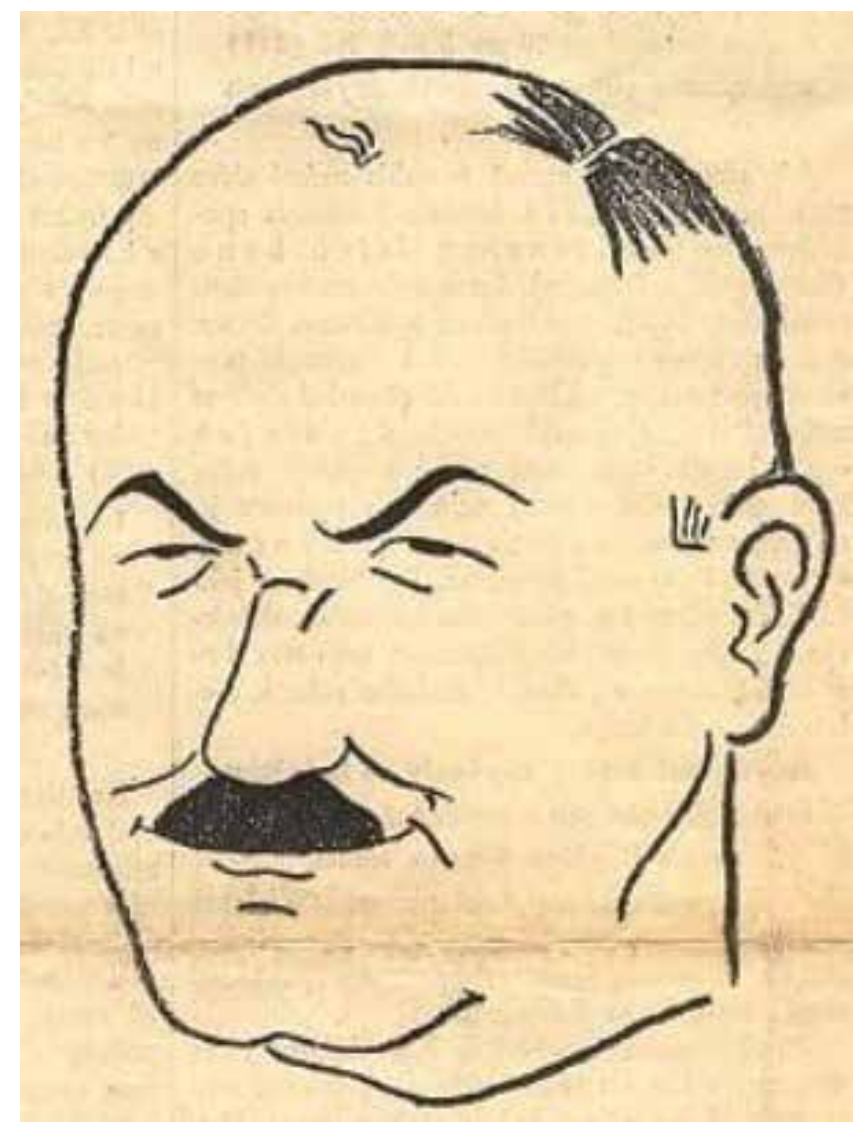

Obr. 4. Portrét O. Podhajského (kresba v dobovém tisku).

Sokol, jež vzniklo také z popudu Podhajského). ${ }^{23}$ Rozkládal se mezi ulicemi Průmyslová a Dolnoměcholupská a z jižní strany jej ohraničovala železniční trat' 221 do Benešova a nová železniční zastávka Praha-Hostivař. Od trati k němu Z východu vedla železniční vlečka. ${ }^{24}$

Jacqueline charakterizuje tovární komplex Ing. Podhajského v prvním pražském dopise matce takto:

„Hostivář [sic!] je úplný venkov (ale administrativně patři k Praze). Žádné lesy, nic než holá planina a hnědá zem, a také závody a továrny. Zdá se, že podnik pana Podhajského je významný: velká továrna, v př́zemí domu jsou kanceláře. Je vidèt mnoho mistrů a inženýrů spolupracujících s p. Podhajským [závod měl v roce 1930 něco přes 500 zaměstnanců a před druhou světovou válkou jich bylo už 600, pozn. JK]. Myslím si, že p. Podhajský musí mít své vlastní auto a svého řidiče - ale nevyuživá toho. Jen tehdy, když jede někdo do Prahy. Je to auto z fabriky, pokud jich

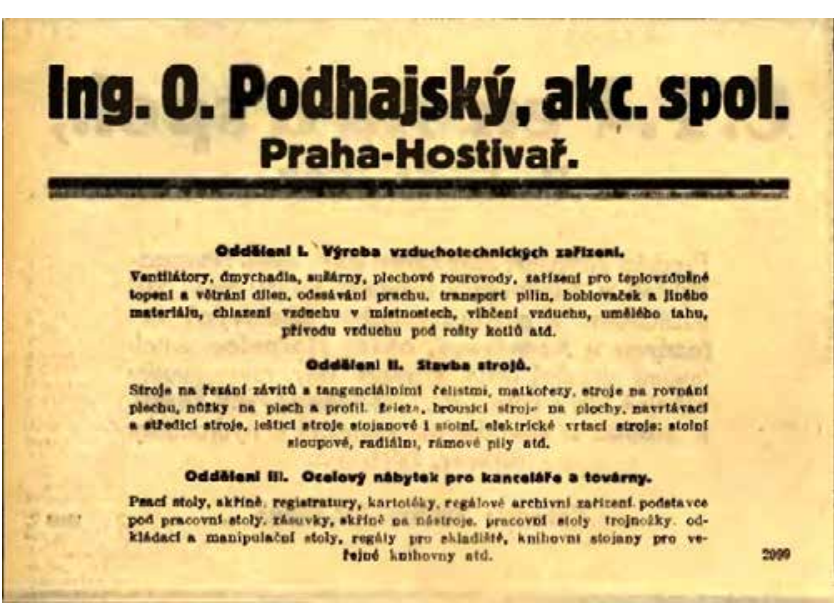

Obr. 5. Dobový inzerát propagující výrobky Strojírny O. Podhajského (Národní listy 27. 10. 1928, dostupné on-line).

není víc - ti, kteři často jezdi do Prahy služebně, ho použivaji, když je to možné. Když není auto, které jede do Prahy, jedeme tam vlakem nebo autobusem, je to 20 minut. Vlaky nám jezdí pod okny a je to důležitá trat', myslím ta z Vidně. " 25

Podhajští měli tři dcery o něco starší než Jacqueline jednadvacetiletou Ludmilu, devatenáctiletou Annu a sedmnáctiletou Helenu. Osudy dcer Podhajských v dospělosti se podařilo zjistit (ovšem, zda se jako dospělé s Jacquelinou stýkaly, nám známo není). Nejstarší z nich Ludmila (19131998), zvaná Lida, Lidla nebo taky „Duna“, se v roce 1939 provdala za Slovince Hinka Pogačnika (1913-2015), s nímž měla tři děti (Janu, Otokara a Patricii). Inženýr Pogačnik studoval techniku v Praze, kde se oba mladí lidé seznámili. Žili ve Slovinsku, Itálii a také v Argentině. Pogačnik byl v Jižní Americe velmi úspěšný (založil společnost, která dodávala zařízení pro těžební, cukrovarnický a tabákový průmysl

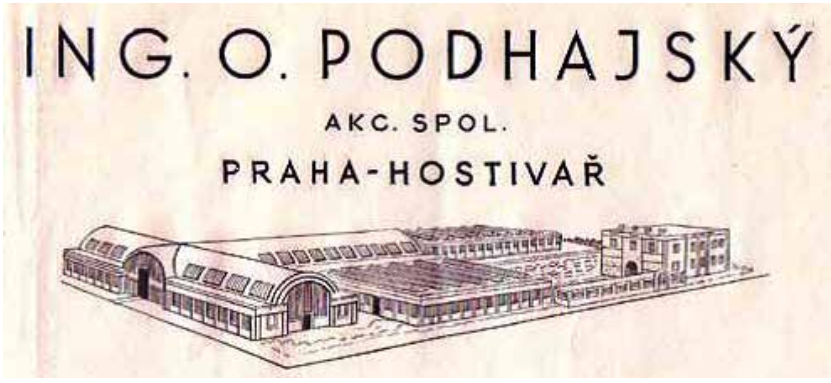

Obr. 6. Reklama závodu O. Podhajský (dostupné on-line).

\footnotetext{
${ }^{23}$ Bohumil Hypšman (1878-1961, do roku 1945 užíval německé podoby jména Hübschmann) vyprojektoval pro industriální čtvrt Hostivaře na severní straně od železniční trati další tovární komplexy, mezi nimi např. Filmové ateliéry Host, Hostivařské mlýny a pekárny nebo Pražské sklárny. Viz ZDEŇKOVÁ 2017 a BERNÝ 2019.

${ }^{24}$ Rozvoj průmyslu nastartoval rozvoj železniční dopravy: přes obec Hostivař byla na konci 19. století budována trat' z Vídně do Prahy. Obyvatelé Hostivaře mohli cestovat vlakem už od roku 1882 (malé nádraží čp. 106), od roku 1905 měla pak obec novou nádražní budovu (čp. 165). Hostivař patř́ k nejstarším obcím připojeným v roce 1922 k Velké Praze.

${ }^{25}$ „Hostivár [sic!] est en pleine campagne (mais administrativement, il fait partie de Prague). Il n'y a pas de bois, rien que la pleine nue et la terre brune. - et aussi des usines et des fabriques. L'entreprise de M. Podhajský paraît importante: la fabrique est grande - le rez-de chaussée de la maison est occupé par des bureaux. - On voit beaucoup de contremaîtres et d'ingénieurs collaborant avec M. Podhajský. Je crois que M. Podhajský doit avoir sa propre auto et son chaufeur - mais on ne l'utilise pas. Ces fois que quelqu'un va à Prague. Il y a une auto pour de la fabrique - si ce n'est plusieurs - qui vont très souvent à Prague pour les affaires on en profite quand c'est possible. Quand il ne se trouve pas d'auto allant à Prague, on y va par le train ou l'autobus: c'est 20 minutes. Les trains passent sous nos fenêtres et c'est une voie importante celle de Vienne je crois. Beaucoup de rapides passent là, mais sans s'arrêter. “”
} 


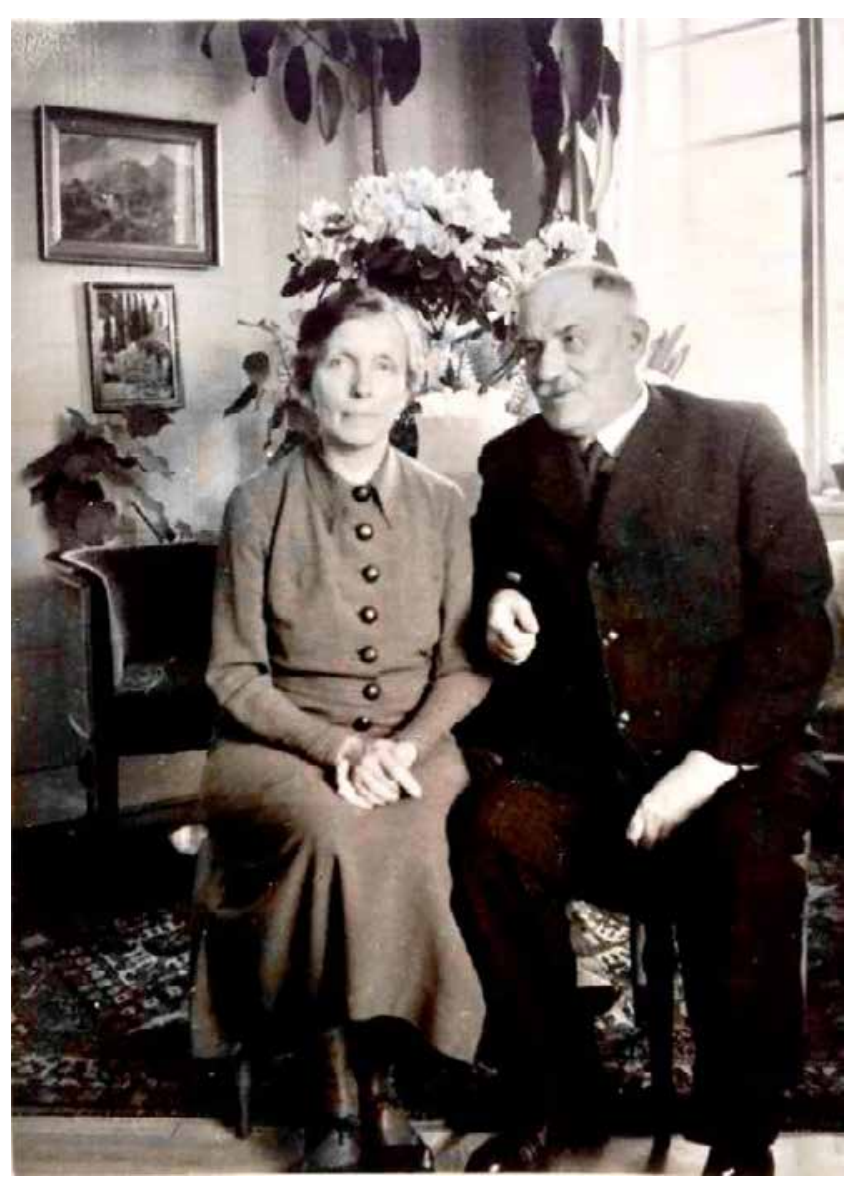

Obr. 8. Anna Podhajská-Šmidáková s manželem (dostupné on-line).

v severní Argentině, Bolívii a Paraguay). ${ }^{26}$ Prostřední dcera, o tři roky starší než Jacqueline, Anna, které se ř́́kalo „Áča“ (1915-2002), se provdala v Hostivaři roku 1938 za Emila Šmidáka (1910-2003). Manželé žili ve Švédsku a ve švýcarském Luzernu, kde jsou též pochováni, společně se svou dcerou Janou provdanou Héraud (1941-2008). Emil Franken Smidak, jméno, pod nímž je znám ve světě, původem z Ostravy, nositel čestného doktorátu filozofie Karlovy univerzity, se profesně věnoval těžkému průmyslu, ale jeho zájmy byly mnohem všestrannější (publikoval např. práce o hudbě, výtvarném umění, filozofii i ekologii). ${ }^{27}$ Nejmladší dcera Helena (1917-1999) si vzala stavebního inženýra Jana Schieszla (1908-1999), syna politika a zastánce idejí Tomáše Garrigua Masaryka Josefa Schieszla (1876-1970) a Ludmily Schieszlové, dcery slavného filologa Jana Gebauera. Schieszl jr. převzal po tchánovi vedení firmy a přijal jeho jméno - vystupoval jako Jan Schieszl-Podhajský. ${ }^{28}$

Rodina Mazonových se s Podhajskými evidentně znala již z dřívějška. Jejich dcera Lída již ve Francii díky vzájemným kontaktům obou rodin na ,poznávacím a jazykovém

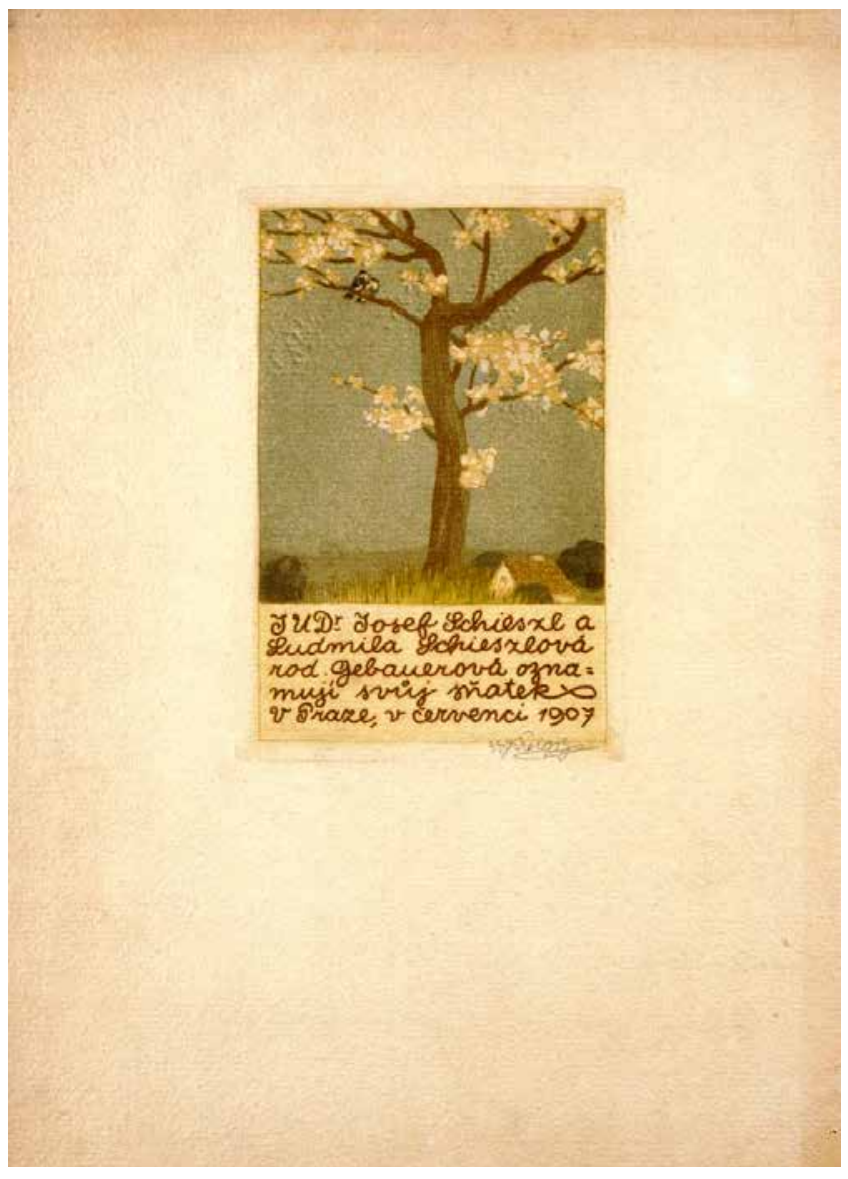

Obr. 9. Vojtěch Preissig. Svatební oznámení JUDr. Josefa Schieszla a Ludmily Schieszlové, roz. Gebauerové v roce 1907 (Národní muzeum - Knihovna Národního muzea, e-sbírky).

pobytu“ byla a Anna se tam chystala v roce 1935 , jak o tom svědčí dopis Jacqueline matce z 27. září (viz dopisy níže). Plánovanou cestu Anny Podhajské do Francie potvrzuje její dopis z 11. ledna 1935 adresovaný Jacquelině do Paříže; dochoval se jako součást souboru Jacquelininých „pražských“ dopisů. Anna v dopise $\mathrm{z}$ Jiřetína reaguje částečně $\mathrm{v}$ češtině a částečně francouzsky na dopis Jacqueline, která se jí ptá, kdy chce přijet za ní tohoto roku do Francie (ta odpovídá, že to záleží na tom, jak bude trávit prázdniny Jacqueline, ona že se přizpůsobí a že ,, by to bylo asi v zář́l “). Anna v Jiřetíně pracuje od podzimu 1934 jako úřednice $\mathrm{v}$ kanceláŕi a zdokonaluje se v němčině. ${ }^{29}$ Popisuje, jak strávila Vánoce (odjela z Jiřetína za rodinou do Hostivaře), jaké byly dárky a jak trávila volný čas. Stěžuje si, že v Praze pršelo a bylo škaredě, a tak hrála doma na klavír a dvakrát zašla do kina, podruhé na francouzský film Poil de carotte ${ }^{30}$, který se jí velmi líbil. Silvestra strávila už v Jiřetíně, užila si zábavy se známými a dobře se bavila až do 5 hodin do rána. S novým rokem opět pracovala $\mathrm{v}$ kanceláři a volné měla jen večery,

\footnotetext{
${ }^{26}$ Nekrolog H. Pogačnika viz DW DOSSIERWEB 2015.

${ }^{27} \mathrm{~K}$ jeho osobě viz BDČZ SMIDAK a MIKLOŠKO 2009.

${ }^{28}$ Ke genealogii rodiny Podhajských viz podrobněji MYHERITAGE. K osobní pozůstalosti Jana Schieszl-Podhajského viz pozn. 18.

29 Jiřetín pod Jedlovou, německy Sankt Georgenthal, významné středisko zimních sportů v Jizerských horách, bylo před druhou světovou válkou město s převahou německého obyvatelstva.

${ }^{30}$ Česky Zrzek; film z roku 1932 natočený volně podle autobiografického románu Julese Renarda.
} 
kdy docházela na hodiny němčiny $\mathrm{k}$ jednomu úředníkovi, ${ }^{31}$ chodila na procházky nebo sáňkovala. Sněhu, kterého napadlo přes $40 \mathrm{~cm}$, si užívala bohatě o víkendech (sáňkovala na Špičáku a byla na výletě na Malé Jizerce). Dopis končí přáním do nového roku (,,Mějte se v Novém roce hezky, jak si sama prejete a brzy mi něco napište. Srdečně Vás zdraví Vaše Ača").

\section{Jacquelinin pobyt v Praze den za dnem}

\section{Dopisy psané z Paříže 29. a 31. srpna 1934}

Otec a dcera Mazonovi cestovali do Prahy společně přes Paříž (patrně z rodinného sídla v Allouis ${ }^{32}$ ). Do francouzského hlavního města dorazili ve středu 29. srpna 1934 a zůstali tam až do pátku 31. srpna.

V prvním dopise z 29. srpna zaslaném matce na venkov Jacqueline píše, že cesta do Paříže byla velice př́ijemná (s otcem měli kupé sami pro sebe). Vypisuje, co všechno museli zařídit po prŕíjezdu do Pařiže a před odjezdem do Prahy. Ona si nechala vyčistit šaty, podrazit boty, koupila si v lékárně nezbytné léky, otec zařídil pasy a koupil jízdenky na vlak; Jacqueline dostala k jízdence navíc slevovou kartu umožňující výhodnou návštěvu Pražského vzorkového veletrhu (sleva 50\%). André Mazon využil trrídenní pobyt v Paříži před odjezdem do Prahy ke schůzce s kolegou, filologem a slavistou Janem Frčkem (1896-1942), tajemníkem čsl. sekce Institutu d'études slaves, ${ }^{33}$ jak to zmiňuje Jacqueline (poté, co společně poobědvali v restauraci Institutu).

Také ve druhém dopise se dcera soustředila na to, aby matce vypsala všechny svoje pochůzky na nákupy - koupi prádla a halenky v obchodním domě „Bon Marché“ , 34 výměnu starých učebnic u „Giberta“635 (s komentářem, že neměli všechno, co potřebovala, a knihy, byt' z druhé ruky, byly drahé) a konečně zamýšlenou koupi zlevněných zelených šati̊, jež se jí líbily, ale tatínek měl výhrady k jejich barvě. Slovní popis doplnila jejich neumělým obrázkem.

\section{Dopisy psané z Prahy 3. - 27. září 1934 \\ „a Hostivářr [sic!] Mardi 3 septembre 1934“36 (3 strany)}

První dopis, který Jacqueline posílá z Prahy, je datován úterkem 3.[sic!] zář́i 1934:37 píše tedy nikoliv v den př́ijezdu v neděli 2. záríi (stručnou zprávu o tom, jak dojeli, však podal ještě ten den večer manželce André Mazon, jak to stojí v Jacquelinině dopise), ani následující den. Omlouvá se, že neměla čas, protože šla v doprovodu Anny navštívit tatínka do hotelu Paříž, kde je ubytován. S tatínkem zašli k Bat'ovi, kde si koupili několik párů bot, a udělali si malou procházku po městě (Karlův most, Malá Strana). S Annou, která si mezitím ve městě vyřizovala svoje záležitosti, se pak vrátila do Hostivaře vlakem za pět minut dvanáct. ${ }^{38} \mathrm{~V}$ pondělí dopoledne si četla s Helenou knížku $B i b i^{39}$ a pak se s ní šla projít po hostivařské pláni (,Hostivař je větší, než by se mohlo zdát: rozkládá se hodně daleko doprava i doleva, jeho části jsou rozptýleny v planině "). ${ }^{40}$

\section{„Hostivářr [sic!], 7 Septembre 1934"6 (6 stran)}

$\mathrm{Z}$ pohledu popisu událostí je tento dlouhý dopis $\mathrm{z}$ pátku 7. zář́ nejvíc neuspořádaný (patrně jej psala s přestávkami a možná ve chvatu). V úvodu děkuje za dopis matky ze 4. záríi, je znepokojena tím, že maminka má opět problémy se zády (bolesti šíje a ramen) a doufá, že jí bude lépe. Omlouvá se, že ve čtvrtek neměla čas psát, protože odpoledne šla s Annou na Pražský veletrh. Jednalo se o Pražský vzorkový veletrh, který se konal pravidelně od roku 1920 (s přestávkami až do roku 1950) dvakrát ročně (na jaře a na podzim) na holešovickém Výstavišti. Propagoval především československé výrobky, ale účastnili se ho nejen domácí, ale i četní zahraniční obchodníci. ${ }^{41}$ I když se jí původně jít nechtělo, vzhledem k tomu, že měla vstupenku o polovinu lacinějšíi, ${ }^{42}$ rozhodla se veletrh navštívit. Návštěvy nelitovala. Píše: „, Byla tam pochopitelně velká výstava českého skla, byla tam také velká část vyhrazena francouzským vystavovatelüm a Francii. Na veletrhu jsem si koupila dvě panenky

31 „,... němčina mi jde již dobře. Už se mi také stalo, že jsem místo česky začla mluviti německy, což je nejlepšim důkazem, že už ji mám takřka v krvi, “” svěřuje se Jacquelině.

32 Sídlo Château Vert v obci Allouis, která se nachází asi 20 km od města Bourges, v historické oblasti Berry, dnes v departmentu Cher ležícím oblasti Centre-Val de Loire. Dnes přeměněné na hotel.

${ }^{33}$ Studoval na Filozofické fakultě Univerzity Karlovy češtinu a francouzštinu, v letech 1920-1921 pobýval ve Francii, v letech 1923-1928 působil jako lektor na Národní škole živých východních jazyků v Paříži a jako tajemník čsl. sekce Institutu slovanských studií a zasloužil o zřízení lektorátů češtiny v Lyonu, Lille a Bordeaux. K hlubšímu studiu staroslověnštiny ho podnítil Antoine Meillet (pod vlivem A. Mazona a A. Vaillanta se zaměřil na studium staroruské památky Zádonštiny). V letech 1938-1942 pracoval jako knihovník v pražské Slovanské knihovně (za heydrichiády byl zatčen a popraven).

${ }^{34}$ „Au Bon Marché“ (dnes Le Bon Marché) v Pařǐzi, první obchodní dům ve francouzských dějinách, založený roku 1838. Nachází se mezi ulicemi Rue de Sèvres, Rue de Babylone a Rue du Bac v 7. pařížském obvodu.

${ }^{35}$ Gibert Joseph je slavné pařižské knihkupectví existující od roku 1886 dodnes, jeho hlavní sídlo je na bulváru Saint Michel. Prodává nové i zlevněné a antikvární knihy ze všech oborů (Gibert Jeune se specializuje na školní učebnice, především z druhé ruky).

${ }^{36}$ Místo a dataci dopisů v nadpisu kapitolky uvádíme v originálu (včetně pravopisných zvláštností pisatelky - viz „Hostivář‘) a uvádíme rozsah textu (počet stran).

${ }^{37}$ Jacqueline se spletla $\mathrm{v}$ určení data, v úterý bylo 4. nikoliv 3. září.

${ }^{38}$ Tento spoj využívala nejčastěji.

39 „Bibi. Život děvčátka“ je slavná knížka dánské spisovatelky Karin Michaëlis (1872-1950), česky poprvé vydaná v roce 1929 (další vydání 1930, 1932) vyprávějící životní př́iběhy asi desetiletého děvčátka Bibi, které žije s otcem. Ten její výchovu nezvládá, a tak Bibi odjíždí k babičce hraběnce a dědovi hraběti na zámek Kindebork, kde zažívá různá dobrodružství.

${ }^{40}$ „Hostivár [sic!] est plus grand qu'on croirait: il s'étend très loin à droite et à gauche, par morceaux dispersés dans la plaine. “

${ }^{41}$ K podzimnímu veletrhu v roce 1934 (konal se od 2. do 9. záŕí) srov. Lidové NOVINY 1934.

${ }^{42}$ Při koupi jízdenek do Prahy poskytoval Čedok finančně zvýhodněné vstupné jako bonus - viz výše. 


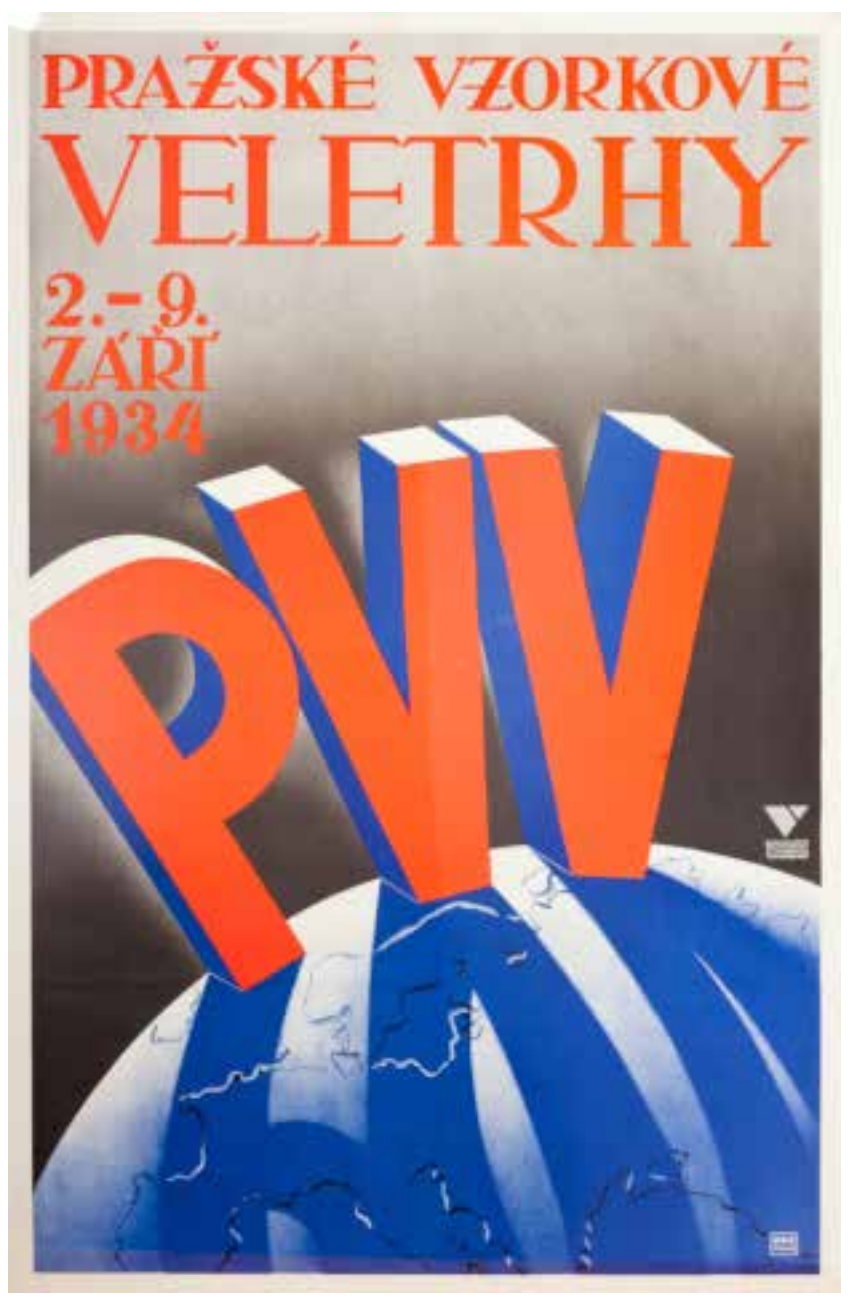

Obr. 10. Plakát Pražského veletrhu v r. 1934 (dostupné on-line).

v kroji (slovenského venkovana a slovenskou venkovanku) a malý barevný dreváček, s nůžkami, náprstkem a pouzdrem na jehly. " ${ }^{3}$ Pak rekapituluje události, k nimž došlo od úterka 4. září, kdy napsala poprvé.

$\mathrm{V}$ úterý odpoledne byla $\mathrm{s}$ Annou na dlouhé procházce v Hostivařském údolí, které je asi půl hodiny od domu Podhajských. Vrátily se až večer s úlovkem hub - z lesa přinesly špičky a bedle, které u Podhajských neznali. Les, upravený na park, se jí líbil a konstatuje, že v neděli tam chodí celá Hostivař na pravidelné procházky. Procházku s Annou využila k tomu, aby se vzájemně učily (česky a francouzsky) názvy stromů rostlin, hub, zvířat a po návratu domů si to všechno zapsaly.

Následujícího dne dopoledne (ve středu) se Jacqueline vypravila za doprovodu Anny za tatínkem do hotelu Paříž. Navštívili Pražský Hrad, chrám sv. Víta a Valdštejnský palác. Na Hradě ji uchvátila architektura sálů (stropy, klenby, schodiště): píše, že je to něco „,entre le roman et gothique“ a že nic podobného nikdy neviděla. Katedrála „St. Výt“ je podle ní krásná, ale uvnitř přecpaná množstvím andělů visících seshora do prostoru, kazatelen, podivuhodných vitráží, z nichž některé nebyly ještě hotové. Vitráže se jí nelíbily, zdály se jí př́liš moderní a hrozné (,,les vitraux sont ultramoderne et affreux "), i když je Podhajští, jak poznamenala, pro jejich barvy obdivují. To, co bylo barokní, včetně obrazu Petra Brandla, českého mistra šerosvitu, který jí připomínal tak trochu Rembrandta, ji př́liš nezajímalo. Zato nádherné obrazy neznámých středověkých českých mistrů ji nadchly; lituje, že je matka nemůže vidět. Nekoupila si žádnou pohlednici, protože nechtěla zdržovat Annu, která na ni čekala. Ale píše, že se tam ještě vrátí sama a koupí si pohledy Prahy, fotografie obrazů a uměleckých děl. Na zpáteční cestě ji v jedné výloze zaujaly panenky nikoliv ve slovenských, ale v českých krojích, které byly mnohem lacinější než ty, které koupila na Veletrhu (ještě si je koupí, stojí 12 Kč a jsou větší, slibuje si). Ve Valdštejnském paláci si prohlédla sály plné obrazů a velice zajímavou výstavu všech dobových dokumentů týkajících se Valdštejna a třicetileté války. Zahrada je podle ní krásná, ale byla by ještě hezčí, kdyby tam nebyly umělé skály a kdyby galerie se sochami nebyla přeplněna umělými krápníky. Prašnou bránu už viděla mnohokrát, a tak se vrátily domů vlakem v $11 \mathrm{~h} 55$. Ke kráse pražských památek čteme pak v závěru dopisu toto milé vyznání: „,To, co mám moc ráda v Praze, jsou staré věže, takové jako Prašná brána (u hotelu Pařiž) (la „Prašna brána“), věže mostu Karla IV., které se jí hodně podobají. V̌sechny staré domy a v̌̌echny zvonice, jež vidime se tyčit nad městem, když se díváme z okna Defenestrace (to je jedno z oken, odkud je nejhezči výhled). "44 Odpoledne strávila na tenise, hrála v družstvu s Annou, Helenou a Mlle Červenou. ${ }^{45}$ Hru nepočítali, protože „Hrát znamená vyměňovat si míče (česky pinkati) "46, jak poznamenala $\mathrm{v}$ dopise Jacqueline. Večer ji Anna vzala do Národního divadla na operu Rusalka, , historii Malé mořské víly od Andersena “ (,,histoire de la Petite Sirène d'Andersen "). Matce při té prŕiležitosti napsala, že ty „, belles robes “, které jí radila, aby si vzala s sebou, jsou jí k ničemu. Do divadla si vzala své nové zelené šaty, velmi jednoduché, ale velmi hezké. Patrně byly i tak prŕliš sváteční, nebot' „Anna avait un costume encore moins habillé" (,Anna byla oblečena ještě mín svátečněji “) a Jacqueline byla zjevně ráda, že si nevzala ty parádní růžové nebo ty zelené vyšívané. Píše, že tatínek má v plánu pozvat Annu a Helenu v sobotu večer do divadla (že odjíždí z Prahy až v neděli nebo v pondělí). ${ }^{47}$

Ve čtvrtek pokračovaly s Annou v naplánované prohlídce Prahy. Vyvezly se na Petřín (,,colline qui fait face du Hradčany") lanovkou. Pak ji Anna nechala sejít celý kopec,

\footnotetext{
43 ,...il y avait naturellement une grande exposition des verres tchèques, il y avait aussi un grand emplacement réservé à la France et aux exposants français. J'ai acheté à la Foire deux poupées en costume (un paysan et une paysanne slovaques) et un petit sabot colorié, avec les ciseaux, le dé, et l'étui a aiguilles."

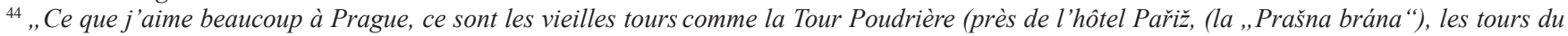
pont Charles IV, que lui ressemblent beaucoup. Toutes les vieilles maisons et tous les clochers qu'on voit se dresser au-dessus de la ville quand on regarde par la fenêtre de la Défenestration (c'est une de celles d'où l'on a la plus belle vue). "

${ }^{45}$ Nepodařilo se identifikovat.

46 „, Jouer, c. à. d. faire des balles (en tchèque pinkáti)“.

${ }^{47}$ Tj. 9. nebo 10. záríí.
} 
aby jí ukázala dole Máchův pomník a znovu, už pěšky, vystoupaly na kopec, kde si prošly bludiště, prohlédly dioráma, tj. boj Pražanů se Švédy na Karlově mostě při švédském obléhání Prahy v roce 1648, a vylezly na rozhlednu „,podobající se Eiffelově věži" (,,une espèce de Tour Eiffel"). Byl odtud nádherný výhled na Prahu a její okolí, přestože byla trochu mlha. Jacqueline se přiznala, že ještě na pařížské Eiffelovce nikdy nebyla a že to bude muset napravit, protože to vypadá dosti hloupě, když na věži, na niž všichni cizinci pějí chválu, ještě nebyla. Poté sešly přes petř́nské zahrady k „,Narodopisnimuseum “, které shledala jako „,très curieux “. Prohlédly si tam velmi zajímavý český a slovenský nábytek, obdivuhodné kroje, do nichž byly oblečeny voskové figuríny, fajáns, talíře, májky, slaměné panáky, různé podle ročních období, které se nosily o svátcích, obrovské šperky a svatební věnce. Na oběd jela autobusem k „,Mme Schieszel “ [= Ludmile Gebauerové], která na ni byla velmi milá - po obědě jí dovolila sednout si na deku na trávník do kouta zahrady s kupou ilustrovaných časopisů a knih. V 5 hodin přišla ,,Mme Dolghoroukova “48 a dvě další dámy, přítelkyně paní Schieszlové. V půl sedmé se všechny rozloučily a „Mme Dolghoroukova“ ji doprovodila kus cesty na autobus (měly stejnou cestu). Jacqueline ocenila, že ji paní Schieszlová ihned oslovila křestním jménem, zatímco paní Podhajská jí stále říká slečno (a její dcery ještě někdy taky). ${ }^{49} \mathrm{Na}$ jiném místě dopisu pak však dodává: „Pan a pani Podhajských jsou velice laskaví. Mladé divky jsou velmi prirozené a velmi milé. "50

$\mathrm{V}$ pátek dopoledne se procházela s Helenou v zahradě a četly česky Bibi, tak jak předtím po tři dny.

\section{„[Hostivař] lundi 10 septembre 1934“(7 stran)}

V pondělním dlouhém dopise píše, že v sobotu odpoledne šla s tatínkem navštívit ,Mme Vokhounovou “, 51 u níž se setkali s Mme Schieszlovou, př́telkyní Podhajských, ,Mme Dolghoroukovou " a manžely Leichterovými. ${ }^{52} \mathrm{~S}$ paní Schieszlovou a paní Leichterovou Jacqueline hovořila česky. Tatínek pak pozval Annu a Helenu do Vinohradského divadla na hru Double (ou la Sosie) de l'impereur (Císařský dvojnik). ${ }^{53}$ Před divadlem povečeřeli $\mathrm{v}$ Obecním domě. Seděli v lóži a dobře viděli. „Hra není príliš chytrá, ale je velice zábavná a dobře zahraná, " "54 sděluje matce a podrobně ji seznamuje s jejím obsahem.
Neděli strávila s Podhajskými na Karlštejně (Karlově Týnu). Kromě prohlídky hradu také hledali houby na nedalekém kopci. Byla s nimi i slečna Podhajská, sestra pana Podhajského (,teta Klemi“) která se v houbách velmi dobře vyzná. Kromě bedlí našli chutné ryzce a hřiby podborováky. Nicméně bedlím, které našla Jacqueline (mamince píše, že byly vysoké, s tenounkou nožkou a dobře zřetelným prstencem, tak jako u nich v Château Vert) prŕlišs nedůvěřovala. Tetička (,, la petite tante"), jak jí Podhajských děvčata říkají, pozvala Jacqueline na návštěvu základní školy, kde je reditelkou. ${ }^{55}$

Pasáž, v níž Jacqueline líčí návštěvu školy, je velmi zajímavá. Do školy šla $v$ pondělí (tj. 10. záŕí) dopoledne a účastnila se tři vyučovacích hodin. Byla na hodině české gramatiky, kde probíraly v primě (děti ve věku 9-10 let) syntax - věty hlavní, pak v nejvyšší třídě, v kvartě (13-14 let), kde se probíral vznik a rozdělení jazyků a způsob jazykových změn. Po přestávce, kdy si prohlédla předměty nachystané na kreslení, se účastnila hodiny němčiny, kde byla překvapena tím, že dívky toho mnoho neznají. „O prestávce v $10 \mathrm{~h}$ mi velice milá paní, která je také profesorkou němčiny, ukázala kreslírnu, kde jsem viděla krásné bedly a jiné houby, květiny a zajímavé predměty, které paní ředitelka pripravila na kreslení. Po přstávce jsem byla v kvartě na hodině němčiny (žačky toho moc neznají, po třech letech němčiny). Neuméjí ani časovat slovesa sein a haben a dávají sloveso $v$ singuláru k podmětu, který je v plurálu. " ${ }^{66}$ Domů se musela vrátit už v poledne (vlak 11h 55), na Wilsonovo nádraží ji přes veřejný park doprovodila jedna žákyně z kvarty a Jacqueline litovala, že se nemohla zúčastnit čtvrté dopolední hodiny - zeměpisu v kvartě. Slečna Podhajská ji pozvala na pátek odpoledne na prohlídku Prahy. Jacqueline píše, že půjde i s Annou: „Anna půjde také. Protože Anna ani Helena mě nenechaji dělat nic samotnou: pokaždé když jedu do Prahy, tak shodou okolností jedna nebo druhá tam jede také, aby si vyř́ldila svoje záležitosti. Nevím, zda je to ze zdvořilosti, nebo z obavy pustit mě samotnou. Takže jsem ještě ani jednou sama do Prahy nejela. Kdyby to nebylo tak daleko, jela bych, aniž bych jim to řekla; zejména ted', kdy jsem objevila, jak mohu opustit svi̊j pokoj, aniž bych musela projit pres pokoj divek. Je propojenýs piodou, odkud vedou malé dveře na schodiště. Ale Praha je vlakem 20 minut odsud, ne víc, nic na tom není. Ráda bych věděla, zda tomu

\footnotetext{
${ }^{48}$ Marie Scherrer-Dolgorouky (1902-?), spisovatelka, překladatelka z ukrajinštiny, profesorka na Lycée Français de Prague, od roku 1940 knihovnice v Knihovně Institutu slovanských studií v Paříži. Viz PROVENIO DATABÁZE https://provenio.net/records/ $f_{c} 8 a e f 1 b-872 e-4 b 01-a 19 f-0 e 064 d e 72 e c 7$.

49 „Mme Podhajská m'appelle toujours slečno, et ses filles encore quelque fois. “

${ }^{50}$ „M. et Mme Podhajský sont très gentils. Les jeunes filles sont très simples et très gentilles. “

${ }^{51}$ Francouzská bohemistka, lektorka francouzštiny, knihovnice Francouzského institutu E. Denise v Praze Madeleine David-Vokounová (19021989). K ní podrobněji KAŠPAROVÁ 2020, s. 11-13.

52 „Jeden mladý český profesor se svou ženou“ (,, Un jeune professeur tchèque avec sa femme“). Nepodařilo se identifikovat.

${ }^{53}$ Napoleonská veselohra „Císařský dvojník“ od Jiř́ho Wernera se hrála toho roku v Městském divadle pražském na Vinohradech.

54 „La pièce n'est pas bien maligne, mais elle est très amusante. “

${ }_{55}^{5}$ Slečna Podhajská učila na měšt'anské dívčí škole na Starém Městě od roku 1914.

${ }^{56}$ „A la récréation de 10h, une dame très gentille, qui est aussi professeur d'allemand, m'a montré la salle de dessin, où j'ai vu les belles lépiotes, et d'autres champignons, fleurs, et objets curieux trouvés par la directrice, prêts à être dessinés. Après la récréation, j'ai suivi le cours d'allemand en $4^{e}$ année (les élèves n'en savent pas beaucoup, après trois ans d'allemand. Elles ne savent pas même conjuguer sein et haben, et mettent un verbe au singulier après un sujet au pluriel). “
} 
bude $i$ ve středu, až půjdu na oběd k paní Schieszel, “ postěžovala si matce. ${ }^{57}$ Ráda by si pražské památky prohlížela sama, chodila svým tempem a pomaleji: „,Méla bych velkou chut' navštivit Prahu sama, podivat se do historických čtvrtí a tam, kam mi tatínek radil zajít, ale Anna rozhodla, abychom si každý den udělaly nějaký program a že mně Prahu ukáže podle tohoto programu. Ovšem navštivit Prahu, to pro ni znamená kráčet velice rychlým krokem a s neustále vážným a odhodlaným výrazem mi vyjmenovávat vše, co vidíme, aniž bychom se na okamžik zastavily. Takto jsme procházely Prahu na jeden zátah a vracely se pres veletrh, který je na druhém konci města na kopci. "58 Jacquelininy obavy, že až ve středu přijede domů Helena, bude její nepozorovaný odchod z domu ještě komplikovanější, se stupňovaly: , Lida, nejstarši ze tř́ sester, má přijet ve středu v 6h. Když budou tři, nebudu už moci být sama ani na okamžik. Dá mi už dost práce, abych sama byla, když jsou jen dvě. Když se odeberu psát, ř́kaji mi, že píšu hodně často (a to nepišsu víckrát než jednou za tři dny). A navíc mohu použit průchod z půdy jen pro odchod ze svého pokoje, protože z druhé strany je stále zamčený. Abych se dostala $k$ sobě do pokoje, musím pak projít přes pokoj Anny a Heleny. Překvapuje mè, že ještě od oběda pro mě nepřišly (je pưl čtvrté) a obědvali jsme v 1 hodinu. Je to poprvé, kdy jsem 2 hodiny sama. Překvapuje mě také, že dnes odpoledne Anna ještě nerozhodla, co bude na programu a neprobrala to se mnou. Ale možná, že mi to daji vědět každým okamžikem. "59 Zjevně si však následně uvědomila, že si na svůj pobyt a na Annu poněkud stěžuje, a tak se v závěru dopisu snaží matku uklidnit: „Promiň, mami, právě jsem si prečetla svi̊j dopis, je hloupý. Cítím se zde velmi dobře, jsem velmi št’astná, že tu jsem, a v̌̌echno, co jsem zde viděla, je velice zajímavé. Anna a Helena jsou stále milé a velice laskavé. Nejdřvive jsem si myslela, že bych si mohla lépe rozumět s Annou, ale od třetího dne si víc rozumím s Helenou, která je dokonce až poněkud př́liš dětská. " ${ }^{60} \mathrm{Na}$ prosbu matky píše o své návštěvě u Bati (zmiňovala se o ní již v prvním dopise) a o tom, z jaké látky jsou zelené slavnostní šaty. Nabízený sortiment obchodu Bat’a oceňuje a pochvaluje si, že tam sehnala všecko, co jí matka kupuje v Pařiži, a to za velice dobrou cenu. „,Neptali se mě tam na moje jméno, aby mi vystavili kartičku a tu tatínkovu nehledali. Maji nepochybně přiliš mnoho zákazníků, kteři jejich zvyklosti nedodržuji. Koupila jsem si tam hezké hnědé střevičky, ale obyčejné a masivní, a šedé střevičky; které vypadaji o něco víc elegantněji, $i$ když jsou také hodně jednoduché. Každý pár za 49 Kč, tj. ca 30 frcs. Nejsou vůbec drahé. K tomu tři páry pořádně silných, ale hezkých punčoch, po $16 K \check{c}$ (skoro 11 frcs) a jeden pár šedých hedvábných za 25 Kč (15 frcs). Je to mimořádně dobrý obchod, protože jsem tam koupila ty, které mi kupuješ v Pařiži. A možná jsou dokonce o něco jemnějši než ty, které obyčejně nosím. Pokud jde o mé zelené šaty, jsou, myslim, napưl z hedvábí, napưl z príze. Tu látku neznám. “61

\section{„Hostivár̆, jeudi 13 septembre 1934“(2 strany)}

Ve čtvrtečním dopise Jacqueline potvrzuje př́jem matčina dopisu, který dostala ve středu večer po návratu od Schieszlů, a sděluje, že v úterý přišel dopis od tatínka, v němž jí v šesti rádcích popisoval, jak se měl celý den v Brně. Pak jako obvykle vypisuje události předcházejících dní.

Pondělní odpoledne strávila na tenise s Annou a Helenou, jak už o tom psala. Byli tam přátelé a př́telkyně obou sester, hráli zápasy, ale ona se jen dívala, nebyla schopna hrát. Večer se vykoupala a umyla si hlavu.

Úterní dopoledne šla na plánovanou prohlídku Prahy s Annou (služební auto je vyložilo někde v moderní čtvrti a ony odtud šly na Staré Město). Cestou navštívily jeden z pražských obchodních domů, úplně stejný jako jsou pařížské Uniprix, a zastavily se v jednom starém kostele, jehož jméno si nepamatovala, ${ }^{62}$ ale kromě gotické architektury se jí moc nelíbil, nebot' uvnitř byl plný „,baroknich křiklavě barevných výtvorů “ (,, constructions baroques et criardes “), podle ní dokonce mnohem více než chrám sv. Víta. Došly až do Starého Města a Jacquelinino vyprávění pokračuje

${ }^{57}$ „Anna viendra aussi. Car Anna et Helena ne me laissent pas faire un pas seule: chaque fois que je vais à Prague, il se trouve que l'une des deux y va aussi pour les propres affaires. Je ne sais si c'est par politesse, ou par crainte de me laisser sortir seule. De sorte que je ne suis pas allée seule à Prague, même une fois. Si ce n'était pas si loin, j’irais sans prévenir; maintenant surtout, car j'ai découvert que je pouvais quitter ma chambre sans traverser celle des jeunes filles. Elle communique avec un grenier, lequel donne dans l'escalier par une petite porte. Mais Prague est 20 minutes d'ici en train, ce n'est plus, et il n'y a rien à faire. Je suis curieuse de savoir si cela va recommencer mercredi, quand j'irai déjê̂ner chez Mme Schieszel. “

58 „J'aurais bien envie de visiter Prague seule, de voir les vieux quartiers et tout ce que papa m'a indiqué, mais Anna a décidé que chaque jour, nous nous ferions un certain programme, et qu'elle me ferait visiter Prague selon ce programme. Or, visiter Prague, pour elle, c'est marcher d'un pas très rapide, avec son air toujours sérieux et décidé, en me disant le nom de tout ce que nous voyons, sans s'arrêter un instant. C'est ainsi nous avons traversé Prague tout entrer, en revenant de la Foire, qui est à l'autre bout de la ville, sur une colline. “

${ }_{59}$ „Lída, l'aînée de trois soeurs, doit arriver mercredi à $6 \mathrm{~h}$. Quand elles seront trois, je ne pourrai plus être seule un instant. J'ai déjà bien de la peine à l'être quand elles ne sont que deux. Quand je me retire pour écrire, elles disent que j'écris bien souvent (je n'écris pourtant que tous les 3 jours). Et je ne peux utiliser le passage du grenier que pour sortir de ma chambre, parce qu'il est toujours fermé dans l'autre sens. Pour entrer chez moi, il faut passer par la chambre d'Anna et Helena. Je m'étonne qu'elles ne soient pas encore venues me chercher depuis le déjeûner (il est 3 h $1 / 2$, et nous avons déjêuné à $1 \mathrm{~h}$.). Voilà la première fois que j'ai $2 \mathrm{~h}$. de solitude. Je m'étonne aussi qu'il n'y ait pas cette après-midi un programme déjà arrêté par Anna sans qu'on m'ait consultée. Mais peut-être va-t-on me l'annoncer dans un instant."

${ }^{60}$ „Pardon, mama, je viens de relire ma lettre, elle est stupide. Je suis bien ici, je suis très heureuse d'y être, et tout ce que j'ai vu jusqu'ici est très intéressant. Anna et Helena sont toujours très aimables et très gentilles. J'ai cru d'abord que je m'entendrais mieux avec Anna, mais dès le $3^{e}$ jour je me suis mieux entendre avec Helena, qui est même un peu trop enfant."

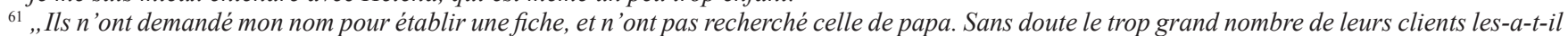
fait renoncer à leur coutume. J'y ai acheté des souliers bruns jolis, mais ordinaires et solides; et des souliers gris d'aspect un peu plus distingué, quoique très simples aussi. Chaque paire: $49 \mathrm{Kc}$, c. à. d. environ 30 frcs. Ils ne sont pas chers du tout. Plus trois paires de bons bas solides, mais jolis, à $16 \mathrm{Kč}$ (presque 11 frcs) et une paire grise en soie, à $25 \mathrm{Kč} \mathrm{(15} \mathrm{frcs).} \mathrm{C'est} \mathrm{extraordinairement} \mathrm{bon} \mathrm{marché,} \mathrm{car} \mathrm{j'ai} \mathrm{acheté} \mathrm{ce} \mathrm{que} \mathrm{tu}$ $m$ 'achetes ordinairement à Paris. Peut-être même ceux-ci sont-ils un peu plus fins que ce que je porte habituellement. Quant à ma robe verte, elle est, je crois, mi-soie mi-fil. Je ne connais pas ce tissu. "

${ }^{62}$ Kostel sv. Mikuláše na Staroměstském náměstí? 




Obr. 11. Dobová reklama na výrobky firmy Bat’a (dostupné online).

líčením zážitků z prohlídky radnice, orloje (dívky se přidaly ke skupině německých turistů) a Týnského chrámu, který se jí opět líbil spíše zvenku než zevnitř. Židovský hřbitov byl sice zavřený, ale návštěva tehdejší Universitní knihovny v Klementinu jim vyšla. Navštívily všechny čtenářské a výpůjční sály (i když je podle Jacqueline prošly poněkud nesystematicky) a muzeum, kde ji opět nadchla část věnovaná středověku.

\section{„Hostivár [sic!], 15 septembre 1934“ (4 strany)}

V sobotním dopise Jacqueline reaguje na zprávu matky, která psala, že je jí lépe a že našla hodně hub. Informuje ji o tom, že také v okolí Prahy, asi hodinu cesty vlakem, je les plný hřibů a také lidí, kteří je sbírají a prodávají za $6 \mathrm{Kč}$ za kilogram (asi 3 frcs 70).

Píše, že ve čtvrtek odpoledne byla na tenise, ale nehrála, hru jen pozorovala, protože byla unavená.
V pátek dopoledne si dívky četly na zahradě Erbenovy pohádky v češtině - v knížečce, kterou Jacqueline koupil tatínek. Byly v ní však pohádky, které už četla dřív u bří Grimmů nebo $\mathrm{v}$ ruských pohádkových knížkách s obrázky Ivana Bilibina $^{63}$ (např. ta o Zlatovlásce). Každou pohádku si pak vypravovaly zpaměti. Odpoledne se opalovala na sluníčku na dece na zahradě s Lídou a Helenou a hrála s nimi Černého Petra. Dívky obdivovaly její bílé vyšívané šaty. Bylo krásně a sluníčko pálilo. Děvčata se opalovala v plavkách, na rozdíl od Jacqueline. Ta se svěřuje matce: ,,Musím si u Bati koupit bílé ponožky: v tomto vedru tady žádná z divek nenosí dlouhé punčochy (pouze, když se jde do města) a ony se stále diví, že je nosím v domě, na zahradě a na tenise. " ${ }^{64}$ Lída ji naučila velice zábavnou hru - dámu, která se hraje s kameny se symboly slunce, měsíce a hvězd a jejíž pravidla jsou trochu odlišná od klasické dámy. $\mathrm{V}$ dopise si Jacqueline také pochvaluje českou kuchyň - buchty, knedlíky se švestkami a knedlíky s masem - a říká, že Podhajští jsou rádi, že jí česká jídla chutnají; i když se Sarah Bernhardtová, jak píše Jacqueline, prý o knedlících vyjádřila, že to bylo „,něco strašného “ (, quelque chose d'affreuse "). Přestože v Čechách obědy a večeře netrvají dlouho a nejsou nijak bohaté, v 10 hodin dopoledne a ve 4 hodiny odpoledne je zvykem svačit dva obrovské krajíce tmavého chleba se slaným máslem a dva kusy ovoce. , J $J i$ se zde jen tmavý chléb a náš bílý francouzský chléb vyvolá vždy přkkvapení; co se týká slaného másla, nebo přesněji řčeno másla, na nějž hodi trochu soli, bylo to chutné a je tomu už hodně let, co jsem je jedla. "65 Podrobně mamince pak popisuje problém tzv. hostivařského tunelu, kterým si obyvatelé Hostivaře zkracují cestu na nádraží. „Nádraži se nachází, vzhledem k nám, na druhé straně velké železniční trati, kterou chrání zdi z obou stran. Dostat se na nádraži nebo $k$ němu znamená vyjít nahoru až $k$ železničnímu přejezdu, a to je hodně daleko. Nebo jít tunelem, který vede pod úrovni silnice, to je 5 minut. Ale tento tunel není ve skutečnosti nic jiného než prechod vybudovaný pro odtokový kanál potoka. Je tam chodnik $50 \mathrm{~m}$ dlouhý a potok teče vedle. Navíc není osvětlen a zápach je tam děsný. Celá Hostivar̆ tento tunel prokliná, ale celá Hostivař ho použivá. Myslím, že minulý rok tam Podhajští instalovali lampu, ale lidé ji rozbili. Správa Hostivaře nechce zř́dit přechod nad úrovní tunelu. Nevím, proč. I když je tunel nepř́jemný, nikdo si na něj nemůže stěžovat, protože je určen pro odpadni stoku a ne pro lidi. Tím hưr pro ty, kteři tudy precházejí. "66

\section{„Praha-Hostivar̆, 20 septembre 1934“ (2 strany)}

V dopise ze čtvrtka píše, že se počasí naráz zkazilo, že je zima, zamračeno, sluníčko nesvítí a je mlha.

\footnotetext{
${ }^{63}$ Ivan Jakovlevič Bilibin (1876-1943), ruský malír, knižní ilustrátor, autor pohádkových ilustrací.

${ }^{64}$ „Il faut que je m'achète des chaussettes blanches chez Bat'a: par cette chaleur, ici, aucune de jeunes filles ne porte de bas longs (sauf quand on va en ville), et elles s'étonnent toujours de me voir en porter dans la maison, dans le jardin et du tennis. “

${ }^{65}$ „, On ne mange, ici que du pain bis, et l'on s'étonne toujours de notre pain blanc de France; quant au beurre salé, ou, plus exactement, au beurre sur lequel on jette un peu de sel, c'était délicieux, et il y a longtemps que je n'en avais mangé. “

${ }^{66}$ „La gare est placée, par rapport à nous, de l'autre côté de la grande voie de chemin de fer, que protègent des murs de part et d'autre. Pour aller à la gare ou à la porte, il faut remonter jusqu'au passage à niveau: c'est très loin. Ou bien prendre de tunnel qui passe sous la rue: c'est 5 minutes. Mais ce tunnel n'est en réalité que le passage ménagé pour un ruisseau d'égout. Il y a un trottoir de $50 m$ de longueur, et le ruisseau à côté. De plus, il n'est pas éclairé, et l'odeur est épouvantable. Tout Hostivář [sic!] maudit ce tunnel, mais tout Hostivář [sic!] l'utilise. Il paraît que l'an dernier les Podhajský y avaient installé une lampe, et qu'on l'a brisée. L'administration ne veut pas faire de passage à niveau au-dessus du tunnel. Je ne sais pas pourquoi - et si le tunnel est désagréable, personne ne peut s'en plaindre ou qu'il est fait pour l'égout, et pas pour les hommes. Tout pire pour ceux qui y passent."
} 


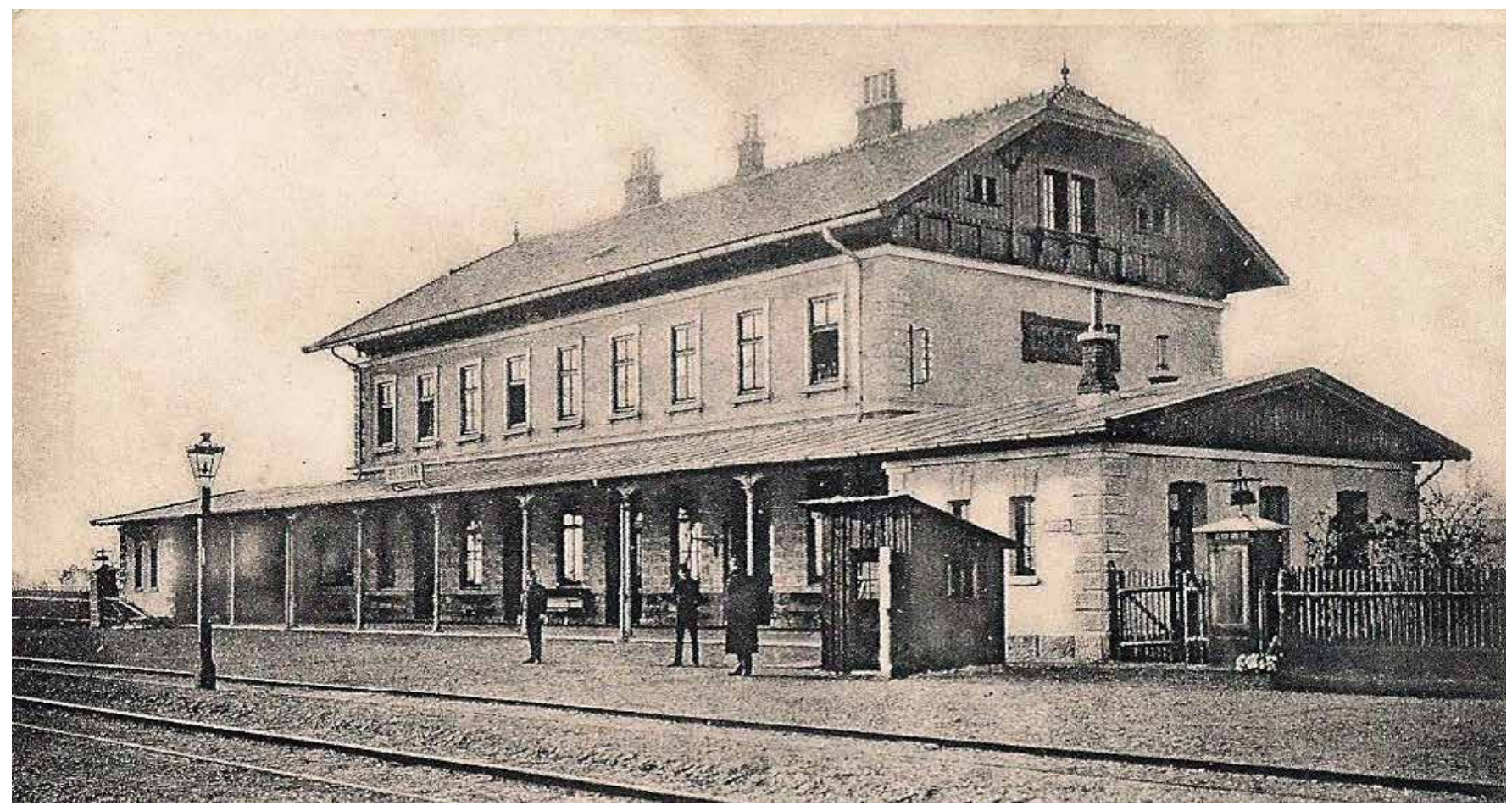

Obr. 12. Nová nádražní budova v Hostivaři (dostupné on-line).

Informuje o návštěvě v rodině Murkư, ${ }^{67} \mathrm{kam}$ šla ve středu. Jacqueline na návštěvu dorazila sama, poněvadž se minuli se synem pana Murka, který jí šel naproti. „,Murkovi jsou velice milí. Ale stačili jsme si ř́ci sotva jednu nebo tři věty česky, protože Mina Murko mluví obdivuhodně francouzsky a syn Murků francouzsky hovoři velmi slušně a protože p. Murko, když hovoří, mluví slovinsky. “68 Př́ítomen byl také sekretáŕ Francouzského lycea, který zná velmi dobře André Mazona a který jim měl ukázat budovu nového Francouzského lycea. ${ }^{69}$ Je známo, že Francouzské reálné gymnázium v pražských Dejvicích (Lycée français de Prague, Gymnase réal) vzniklo roku 1919 a až do třicátých let sídlilo ve třetím poschodí reálky v Ječné ulici. Nová pavilonová budova, areál tzv. Francouzských škol, byla postavena na návrh architekta Jana Gillara, žáka Josefa Gočára, v letech 1931-1934 ve stylu funkcionalismu. V areálu sídlila vedle reálného gymnázia také obecná škola, mateřská škola, pavilon s tělocvičnou a divadlem, bazén, kuchyň a jídelna (plánovaná budova internátu postavena nebyla). Kombinace dvojích oken zajištovala takové prosvětlení celé místnosti, které nevrhalo žádné tmavé stíny. Škola byla po dokončení v roce 1934 fenoménem v celé střední Evropě, jemuž nebylo rovno (zavřena byla $\mathrm{v}$ roce 1939 , po příchodu okupantů). Prohlídka budovy na Jacqueline učinila velký dojem. Je to podle ní supermoderní stavba (i když si Murkovi myslí, že až př́liš) a má zcela nečekaný vzhled (přirovnává ji k obrovským skleněným klecím, po stranách spojených), ale konstatuje, že uvnitř je díky tomu hodně světla a prŕijemně. Po prohlídce školy měla Jacqueline čas tak akorát, aby stihla tramvaj na Wilsonovo nádraží (cesta trvá nejméně tři čtvrtě hodiny), odkud jí jel vlak v půl sedmé do Hostivaře.

V závěru píše, že odpoledne půjde s Annou k její tetě „Klemi“, která je pozvala na společnou procházku po Praze už minulý čtvrtek, ale protože nemohla přijít, byla návštěva odložena na př́ští (tj. tento) čtvrtek.

\section{„Hostivar̆, 23 septembre“ (5 stran)}

V nedělním dopise se Jacqueline vrací ke čtvrteční návštěvě Moderní galerie, ${ }^{70}$ kam zašly s Annou a tetou „Klemi“. Prohlédly si sál s díly francouzských umělců, kde Jacqueline zaujaly hlavně četné krajinomalby. Sál, kde byly „,hrozné obrazy“, jak píše (,,musí to být kubistické obrazy, nikdy

\footnotetext{
${ }^{67}$ Matija (Mathias) Murko (1861-1952), slovinský literární historik, slavista a etnolog, první profesor jihoslovanských jazyků a literatury na filozofické fakultě Univerzity Karlovy (1920-1931), redaktor časopisu Slavia a jeden ze zakladatelů Slovanského ústavu v Praze, kde žil až do své smrti. Srov. HAVLÍKOVÁ 2002. Ke vztahu M. Murka a A. Mazona viz např. ZELENKA 2020. Osobní pozůstalost M. Murka dochovaná v Literárním archivu Památníku národního písemnictví skrývá bohatou vzájemnou korespondenci s A. Mazonem (59 dopisů Mazona Murkovi z let 1921-1951 a 17 dopisů Murka Mazonovi z let 1926-1935).

68 „Les Murko sont très gentils. Mais nous avons à peine dit deux ou trois phrases de tchèque, parce que Mina Murko sait admirablement le français, qu'elle tout a beaucoup à ce que M. Murko fils parle français le plus possible-il le sait assez bien d'ailleurs - et que M. Murko, quand il parle, parle slovène."

${ }^{69}$ K existenci této instituce viz GILLAR 1935 a obšírně, s dějinami Francouzského reálného lycea v Praze, HNILICA 2012, s. 264-472. Viz též STAVEBNICTVÍ A INTERIÉR 2015, LUKEŠ SKRYTÉ POKLADY 2018 aj. Archivní materiál - viz BADATELNA EU. Dostupné z: http:// badatelna.eu/fond/151044/. Fond je nezpracován.

${ }^{70}$ Moderní galerie Království českého či jen Moderní galerie byla česká veřejná sbírka umění 19. a 20. století v letech $1902-1942$ s expozicí na pražském Výstavišti.
} 


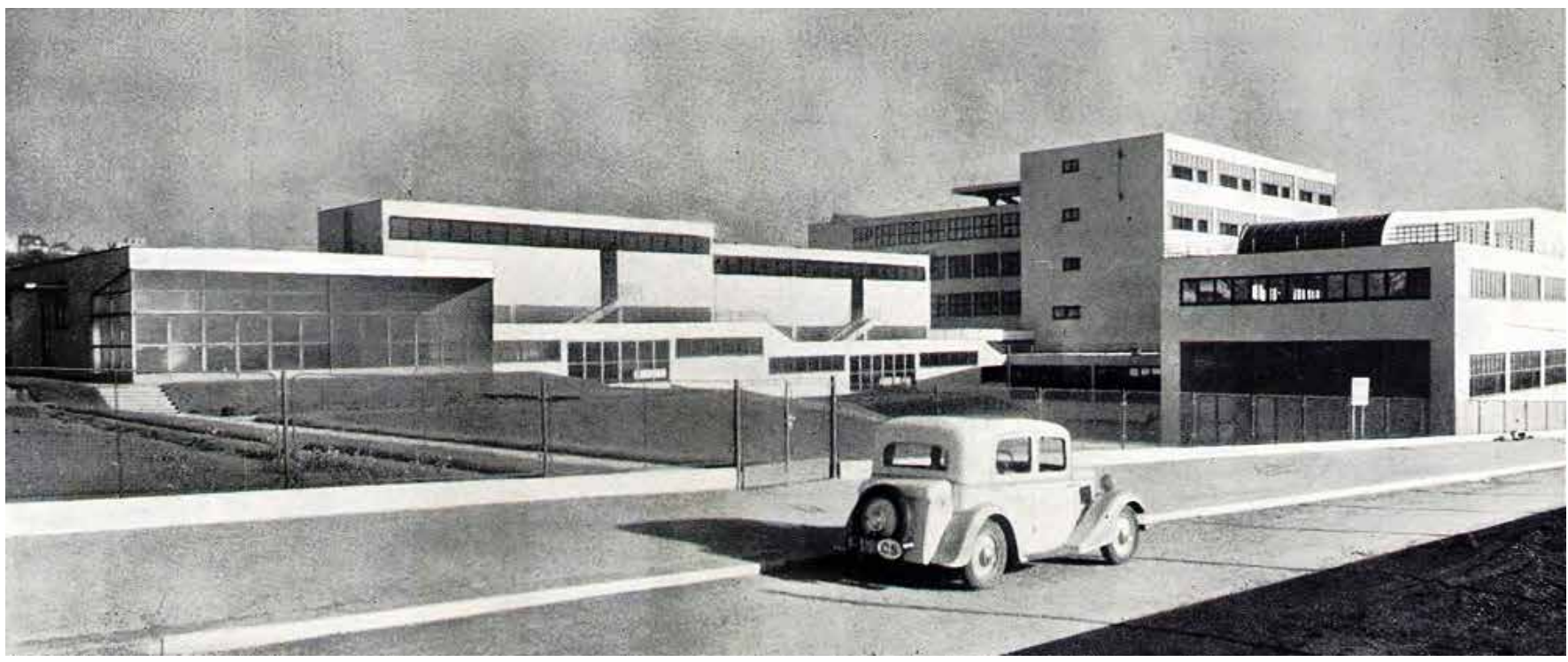

Obr. 13. Dobová fotografie areálu tzv. Francouzských škol (dostupné on-line).

jsem takové neviděla"), ${ }^{71}$ se jí nelíbil. Zašly se rovněž podívat na ,velké panoráma pěkně namalované, jěz predstavuje bitvu, kterou vedli husité “ (tj. na Maroldův obraz Bitvy u Lipan), ${ }^{72}$ a prošly se Stromovkou.

V pátek dopoledne se s Lídou učila gramatiku a dopoledne hned po obědě jela vlakem do Prahy nakupovat dárky. Kromě jiného si koupila R.U.R, knihu, kterou jí tatínek zapomněl koupit, a plán Prahy. Chtěla znovu zajít do muzea v Klementinu, kde byla poprvé s Annou, ale bylo zavřené. Na radu Lídy a Heleny koupila tatínkovi Čapkovy Italské listy a Obrázky z Holandska s jeho ilustracemi. „Zdá se, že je to velice hezké a velmi zábavné čtení (nebudu ti zde vyjmenovávat všechny pochvalné přivlastky, které Lida a Helena užily. Učím se znát postupně všechna ta adjektiva, jež pronesena určitým způsobem, s di̊razem na první slabiku, jsou výrazem nejvyššího obdivu). "73 Při procházce Prahou trochu zabloudila v malých starobylých uličkách Starého Města a vrátila se vlakem v půl sedmé večer. Sestry Podhajských se na ni vrhly, aby ukázala, co si koupila. Zdálo se jí, že mají radost, že si kupuje české a slovenské výšivky.

$\mathrm{V}$ sobotu ráno jela opět za nákupy. Jako dárek koupila Pierrovi ${ }^{74}$ elektrický telefon (velkou kartonovou desku $\mathrm{s}$ barevnými kousky $\mathrm{k}$ vystřižení a $\mathrm{v}$ malé obálce potřebný materiál; návod jen v češtině a v němčině, ne ve francouzštině). Poněkud se obávala, zda se nerozhodla unáhleně a zda se Pierrovi bude dárek líbit. Dále se svěřuje matce se svým „nejdůležitějším“ nákupem, s nímž možná udělala pěknou hloupost, jak píše, ale nemohla odolat. Ve výloze jednoho obchodu s československými lidovými výšivkami viděla šaty, které jí učarovaly. Matce nadšeně sděluje: „Jsou ze sitovité bavlny, béžové (režné) barvy, vepředu, na rukávech a na lemu sukně s velice hezkými červenými výšivkami. Pas a manžety jsou vyznačeny stejně jako u mé mad'arské halenky (vzpomínáš si na ni?). Protože byly na délku o centimetr kratši a v ramenou neseděly, nechala jsem si je upravit: budou hotové v pondělí (to se mi hodí, protože to se zrovna jdu podivat na výstavu hub, kousek odsud). "75

Včera v sobotu odpoledne si udělala pořádek ve svých věcech a účtech. Helena jí udělala vodovou (právě ona onduluje všechny sestry, je to její specialita a umí to výborně - má asi dvacet zakulacených hřebínků, které velmi šikovně zastrkává do vlasů). ${ }^{76} \mathrm{~V}$ sobotu večer telefonovala k Jelínkům, zda se už vrátili z dovolené (15. září psala matce, že jsou ještě pryč). Doma už byli a paní Jelínková pozvala Jacqueline v úterý na oběd.

Jacqueline si uvědomuje, že jí zbývá do pobytu v Praze už jen týden a matce sděluje okolnosti tatínkova a svého odjezdu domů. ,,Tatínek mi psal, že varšavský kongres konči v Krakově, a tudiž se bude vracet přes Prahu, z Prahy pojede 2. ř́ljna a v Pařži bude 3. řijna odpoledne; a já nechci zameškat první den školy. Nevím, co mám dělat. Myslím, že presto odjedu sama 1. řijna, tak, jako jsem to měla dř́ve

${ }^{71}$ „,... une salle consacrée à des tableaux affreux (qui doivent être des tableaux cubistes - je n'en ai jamais vu). “

${ }_{72}^{72}$,... nous sommes allées voir un grand panorama très bien fait qui représente une bataille soutenue par les Hussites. “

${ }^{73}$,...l paraît que c'est très joli et très amusant (je ne te reproduis pas ici toutes les épittetes superlatives employés par Lida et Helena. J'apprends à connaître peu à peu tous ces adjectifs, qui prononcés d'une certaine façon, en appuyant beaucoup sur la $1^{\text {ère }}$ syllabe, sont l'expression de la plus toute admiration). “

74 Pierre Mazon (nar. 1920), mladší bratr Jacqueline.

75 „Elle est en étamine de couleur écrue, avec des broderies rouges très jolies sur le devant, aux manches, au bas de la jupe. La taille et les poignets sont marqués par le même point que sur mon corsage hongrois (te rappelles-tu?). Comme il lui manquait un centimètre de longueur, et qu'elle me serait un peu sous les bras, je l'ai laissée: elle sera prête lundi (cela tombe bien, parce que je vais justament voir les champignons lundi-c'est à deux pas). “

${ }^{76} \mathrm{O}$ nemilých zkušenostech s kadeřnicí v Hostivaři, kam šla nechat si naondulovat vlasy, protože měla strach si to natáčet sama, píše 20. září matce; patrně již neměla odvahu jít tam znovu. „Není to drahé (6 Kč), ale udélali mi to velice špatně; vlasy jsem méla celé slepené a ondulace byla už včera pryč" psala v dopise. 
v úmyslu. " $77 \mathrm{Na}$ konci dopisu přidala doušku (P. S.) - o houbách, které mají právě svoji sezónu. „Hříbky stále zlevňují. Ceny klesly před 14 dny z 10 Kč na 6 Kč za kilo (3 fr 75). Pak ze 6 na 5 a na 4 Kč. V současnosti malé hřibky, ty nejhezčí, nejčerstvější, stoji 3 Kč (asi 1 fr 90) a ty největší 3 Kč 50 (1 fr 50). Také je stále jíme, máme je ve všech jídlech, ve všech omáčkách a ještě se nám nepřejedly. Zdá se také, že na pražských trzich je hub všech druhů plno: žluté hřiby, různé druhy ryzcü, které jsou velice chutné (zde velmi vyhledávané), a mnoho dalších. "78 Sušit je Jacqueline prý však nemůže, u Podhajských je tímto způsobem nekonzervují (nakládají je do octa) a ona by je musela sušit v troubě, což je pro ni jednak obtížné vzhledem k tomu, že je na návštěvě, a jednak na to nemá ani čas. Závidí mamince, že u nich mohou houby sbírat, protože tady se spíše kupují: ,, Tady houby všichni kupujeme, protože do lesů je velmi daleko a hřby se sbíraji od 5 hodin od rána. "79

\section{„Hostivar̆, 24 septembre" (2 strany)}

$\mathrm{V}$ tomto pondělním dopise píše o nedělní návštěvě strýce, tety a „milých“ sestřenic Lídy, Anny a Heleny, ${ }^{80}$ které Jacqueline už jednou viděla, když byly s Annou nakupovat v Paláci Pražských vzorkových veletrhů.

Před nedělním obědem se všechna děvčata šla podívat na „Evgének“, chlapečka starého rok a půl, velice roztomilého a legračního, kterého si dívky Podhajských často „půjčují“ na hraní a rozptýlení, chlapečka sousedky, která vypomáhá v domácnosti u Podhajských a jejíž manžel pracuje v továrně p. Podhajského. Po obědě si všechny dívky povídaly, pak hrály karty. Po svačině hrály volejbal - a to s takovým zápalem, že obě sestřenice zmeškaly vlak a povečeřely u Podhajských.

$\mathrm{V}$ pondělí dopoledne Jacqueline navštívila výstavu hub a pak se jela podívat, jestli je už hotová úprava těch úžasných šatů s červenou slovenskou výšivkou, jak o nich matce psala v posledním dopise. Nebyly drahé, stály $120 \mathrm{Kč}$, tj. kolem 75 frcs. Úprava hotová ještě nebyla, připravit jí je měli až na úterý. Dopoledne chtěla zajít do klementinského muzea a navštívit Židovský hřbitov, ale obě památky byly zavřené. Tak si šla poslechnout pražský orloj - byl tam zájezd Němců s průvodcem, jeho zajímavý výklad se jí líbil.

Odpoledne jí přišel dopis od babičky ${ }^{81}$ a pohled od Ch.Andrého. ${ }^{82}$ Babička psala Jacqueline téměr̆ to samé, co v minulém dopise, a to, co už maminka jistě věděla první (že ji oči zlobí čím dál víc, že píchnutí vosím žihadlem už dávno vyléčila apod.). Jacqueline si četla R.U.R - „,̌esky, samozřjejě “ a ,,bez větších potižzi“. Opět zmínila pozvání na úterní oběd $\mathrm{k}$ Jelínkům a při té př́ležitosti se matce svěřila, že pokud jde o „problém samostatnosti“, že už si nemůže na nic stěžovat. Podařilo se jí totiž jet samotné do Prahy v pátek dopoledne, v sobotu i pondělí dopoledne a samotná bude v Praze i v úterý odpoledne, nepočítá-li návštěvu u Jelínků. A dnešní odpoledne si sama četla R.U.R a pak s Lídou hovořily o Zahradníkově roku. Lída knihu nečetla, a tak jí z ní Jacqueline převyprávěla několik pasáží. A také ji potěšilo, že paní Podhajské je už k ní důvěrnější. Jako doušku připsala: ,,Paní P. mi ted’ ř́ká mým křestním jménem, jak se to sluší."

\section{„Hostivař 27 septembre 1934“(1 1/2 strany)}

Ve svém posledním dopise z Prahy, psaném ve čtvrtek, Jacqueline referuje matce o své úterní návštěvě u Jelínků, kam byla pozvána na oběd. Potkala tam, jak píše „,dámu, jejiž jméno si už nepamatuju, dopisovatelku Národních listů (hlavních pražských novin) v Pařiži. "84 Jelínkovi byli velmi překvapeni, že Jacqueline mluví česky. Před návštěvou si dopoledne znovu prohlédla muzeum v klementinské knihovně a v něm všechny středověké obrazy, které tam byly vystaveny. Chtěla si koupit poštovní pohlednice, ale z těch se starými obrazy měli jen fotografie za $6 \mathrm{Kč}$ (a stejně veliké jako pohlednice) a jen dvě pohlednice, na nichž byly středověké miniatury. Nebyly to podle ní zrovna jedny z nejhezčích, ale přesto si je vzala. „Ale naštěstí mám několik reprodukci ve své tlusté knižce o Praze ", 85 napsala v dopise. Její vyšívané šaty byly už upraveny, a tak si je mohla odnést domů. Padly jí velmi dobře. Když se v nich předvedla před Lídou a Ačou, moc je obdivovaly.

Ve středu dopoledne zanesla na poštu dopis pro tatínka a šla se projít s „Ačou“ po Hostivaři. O tom, kam se Anna chystá po prázdninách, mamince napsala: ,Odjede ve stejnou dobu jako já. Odjiždí do německé oblasti a bude tam až do Vánoc pracovat v kanceláři jako písařka myslím, aby se zdokonalila $v$ němčině. Právě ona by měla myslím pak prijet $k$ nám do Francie (Lida už ve Francii byla a Helena se o jazyky vůbec nezajímá). " ${ }^{86}$ Odpoledne strávila v Praze

\footnotetext{
77 „Papa m'écrit que le Congrès de Varsovie se termine à Cracovie, et que par conséquent son voyage de retour sera par Prague; de Prague que le 2, pour arriver à Paris le 3 après-midi; je ne veux pas manquer la première journée de classe. Je ne sais pas que faire. Je crois que je partirai tout de même seule le $1^{- \text {er }}$, commej'avais pensé le faire d'abord."

78 ,Les cèpes baissent toujours de prix. Ils sont descendus, il y a 15 jours, de $10 \mathrm{Kč}$. le $\mathrm{kg}$ à 6 (3 frcs 75), puis de 6 à 5 , et à $4 \mathrm{Kčc}$. En ce moment, les petits cèpes, les plus beaux, les plus frais, coûtent $3 \mathrm{Kč}$. le $\mathrm{kg}$ (1 frc 90 environ), et les plus grands $3 \mathrm{Kč} .50$ (1 fr. 50). Aussi en mangeons - nous tous les jours, dans tous les plats et à toutes les sauces, et nous n'en sommes pas encore lassés. Il paraît aussi que les champignons de toute sorte foisonnent en ce moment sur les marchés de Prague: bolets jaunes, rousilles, lacteries délicieux (très estimés ici) et autres."

79 "Ici, nous tous achetons les champignons, parce que les bois sont très loin, et que tous les cèpes sont ramassés des 5 h du matin. “"

${ }^{80}$ Patrně př́buzní ze strany matky, protože sestra p. Podhajského „Klemi“ byla svobodná a bratr Jaroslav měl jen jednu dceru.

${ }^{81}$ Matka paní Jeanne-Roche Mazonové; matka Andrého Mazona zemřela v roce 1899.

82 Osobu se nepodařilo určit.

83 „Mme P. m'apelle maintenant par mon prénom, comme cela le doit. “

${ }^{84}$ „.... une dame dont je ne sais plus le nom, correspondante à Paris de Národní listy (le principal journal de Prague)“. Byla to s největší pravděpodobností novinářka a překladatelka Miloslava Sísová (1883-1947). Ve třicátých letech působila jako zahraniční dopisovatelka Národních listů ve Francii a Španělsku. K její osobě viz SKLENÁŘOVÁ 2013 a FDB.CZ SÍSOVÁ.

${ }^{85}$ „Mais, heureusement il y a quelques reproductions dans mon gros livre sur Prague."

${ }_{86}^{86}$ „Elle va dans les régions de langue allemande, et travailler là-bas comme dactylo, je crois, pour perfectionner son allemand, dans un bureau (Kancelař) jusqu'à Noël. C'est elle, je crois, qui doit venir venir ensuite en France chez nous (Lida a déjà été en France, et Helena ne s'intéresse pas tout aux langues). "
} 


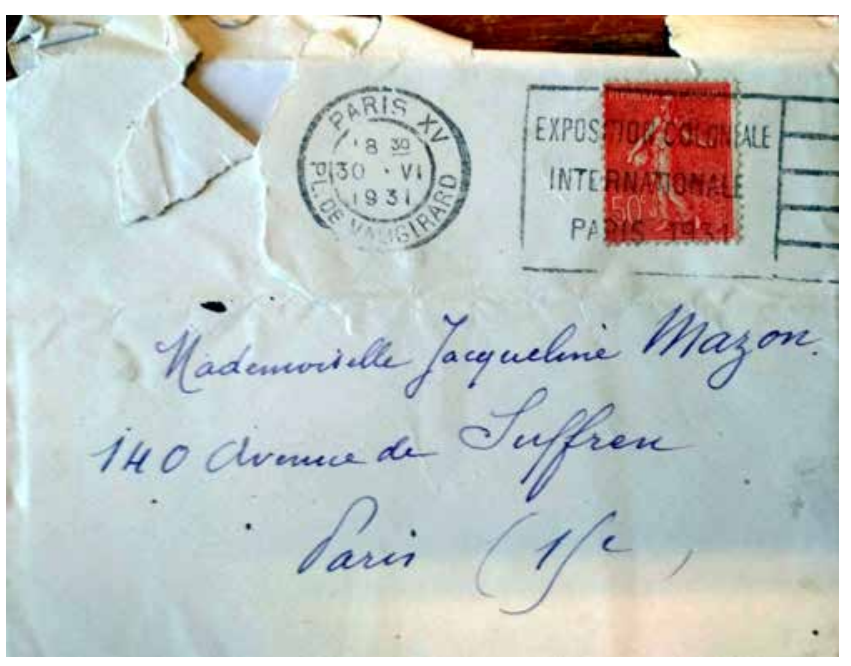

Obr. 14. Poštovní obálka s pařižskou adresou Jacqueline Mazonové v roce 1931 (fond Mazon, archiv Institutu slovanských studií v Pařízi).

a kromě páru černých střevíčků koupených u Bati přinesla také dárek, který měl být překvapením. ${ }^{87}$ Po večeři hrála paní Podhajská na piano a zpívala české lidové písně. Ve čtvrtek ráno se Jacqueline ještě zaobírala oním překvapením a Lída ji před ním vyfotila. V závěru dopisu matce napsala, že odjíždí v pondělí [tj. 1. října] ve $12 \mathrm{~h} 5$ minut a v úterý [2. října] asi kolem 12.30h. přijede do Paříže (Mazonovi měli ve třicátých letech byt na adrese Paris, 140 Avenue de Suffren, na hranicích 7. a 15. obvodu v Paříži, dnes asi $50 \mathrm{~m}$ od stanice metra Ségur linky 10, která tam byla ovšem postavena až v roce 1937). ${ }^{88}$

\section{Zpátky v Paříži}

\section{„[Paris] 15 octobre 1934" (1 strana)}

Jacquelinin dopis matce, napsaný v Paříži, téměř 14 dní po odjezdu z Prahy, lze brát jako jakýsi „epitaf“ její pražské cesty. Paní Mazonová ještě do Paříže nedorazila, patrně kvůli nemocné Jacquelinině babičce, o kterou se starala. Manžel a dcera od ní však marně čekali nějaké zprávy, a protože André Mazon byl z této situace poněkud rozmrzelý, pověřil Jacqueline, aby se matky zeptala, co je s ní a babičkou nového a kdy za nimi hodlá přijet. Pražského pobytu se dopis týká už minimálně: obsahuje pouze Jacquelinino konstatování, že napsala Podhajským a všem, které v Praze navštívila. Dopis je poměrně krátký - dcera sděluje, že se hned po návratu do Paříže vrátila do školy, a tak nemá príiliš času na psaní.

\section{Praha a Pražané roku 1934 francouzskýma očima}

Dopisy Jacqueline představují jakousi formu osobního deníku, $\mathrm{v}$ němž dospívající dívka vypisuje pravidelně svoje každodenní zážitky a postřehy z pobytu v cizině, který pro ni znamenal nepochybně první „reálný dotyk“ s Prahou
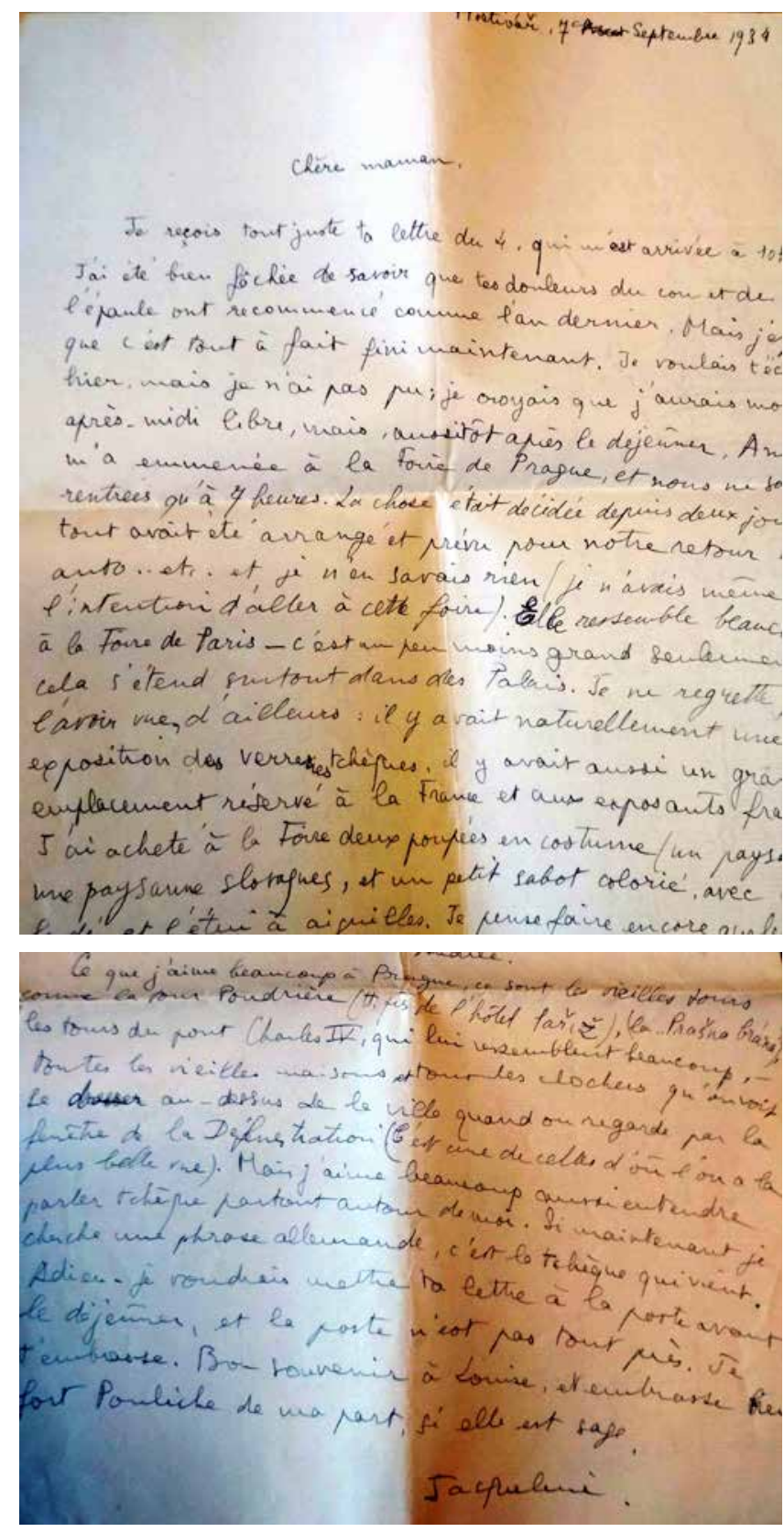

Obr. 15-16. Ukázka textu začátek a konec dopisu Jacqueline Mazonové ze 7. zárí 1934 (fond Mazon, archiv Institutu d'études slaves v Pařízi).

(a Československem vůbec) a jeho obyvateli, s historií a kulturou, zemí, v níž její otec studoval a kde měl spoustu přátel, zemí, o níž tolik slyšela a četla a jejíž jazyk si přijela zdokonalit. Skutečnost, že se tento „pražský““ soubor dopisů dochoval ve své celistvosti, což v prípadě ostatní korespondence zasílané dcerou matce neplatí, svědčí o tom, že si jich adresátka zřejmě vážila a že dopisy pečlivě po léta uchovávala; patrně jako vzpomínku na dceru a na její první pražský pobyt. Ostatně nemusela to být právě adresátka, tj. paní Mazonová, díky níž se dopisy dochovaly. Pietně a s jistou nostalgií je mohla po matčině smrti schovávat sama Jacqueline; se vzpomínkou na své mládí, na své české

\footnotetext{
${ }^{87}$ Byl to patrně dárek pro maminku, takže o tom nepíše nic bližšího.

${ }^{88}$ Dokladem toho je obálka dopisu zaslaného Jacqueline 30. 6. 1931 dochovaná ve fondu Mazon v archivu Institutu slovanských studií.
} 
kamarádky a Prahu třicátých let. I když nemáme k dispozici odpovídající matčiny dopisy paralelně zasílané do Prahy (tj. odeslanou korespondenci) a ani dopisy, které v té době psal André Mazon své ženě nebo dceři Jacqueline do Prahy, když byl pracovně mimo ni, z dívčiny korespondence se dozvídáme zprostředkovaně, prostřednictvím jejích reakcí, také řadu podrobností z rodinného života Mazonových a jejich blízkých ve Francii. Dopisy vypovídají také mnohé o vztahu matky a dcery. Nemáme na mysli však jen ono obligátní francouzské oslovení matky, jímž začíná každý dopis, a závěrečné vřelé pozdravy, jež lze vnímat spiše jako předepsanou zdvořilostní frázi, ale např. dceřiny dotazy na matčino zdraví, dotazy na její aktivity a aktivity dalších členů rodiny, či známých a také Jacquelininy důvěrné informace týkající se nákupů, zejména oblečení, a výhodnosti jejich pořízení (dívka uvádí přesné ceny v Kč a v přepočtu na franky). Výjimečně najdeme i sdělení intimnějšího charakteru (např. Jacquelinino poněkud nečekané hořké postesknutí, které vzápětí bere zpět, o tom, že se v rodině Podhajských ne vždy cítí zcela ,jako doma“). ${ }^{89} \mathrm{Z}$ obsahu dopisů je cítit i náznak vzájemného duševního či zájmového souznění matky a dcery, např. co se týká názorů na umění, vztahu k př́irodě nebo záliby ve sbírání hub. Když např. Jacqueline ličći své dojmy z prohlídky historických památek, zazní v jejím popisu tóny lítosti, že matka s ní nemůže sdílet některé zážitky (při popisu návštěvy chrámu sv. Víta mj. píše: ,, ... velmi lituji, že jsi tam nebyla, abys viděla všechny ty obdivuhodné obrazy neznámých českých středověkých mistrư " "90). Stejně tak lze mezi rádky vyčíst to, že se Jacqueline někdy stýská po domově (závidí mamince její procházky rodným krajem, její výpravy do lesa a sbírání a sušení hub, což dokazují např̀. četné pasáže, v nichž se houby jako téma objevují, a podrobný popis různých druhů hřibů rostoucích v Čechách a jejich srovnávání s houbami ve Francii). Těžko hodnotit, zda měla Jacqueline blíže k otci, či matce, ale faktem je, že často její dopisy a i ona sama fungují jako jakási „,informační spojka“ mezi otcem a matkou; maminku např. informuje o aktivitách otce $\mathrm{v}$ době jeho profesní zaneprázdněnosti a mamince dokonce na otcovo požádání vyřizuje zprostředkovaně určitý důležitý vzkaz. Můžeme se domnívat, že otec-vědec představoval pro dceru jistou intelektuální autoritu, o niž se mohla opríit, které si vážila a která jí pomáhala rozšiřovat intelektuální obzor, ale před níž měla značný respekt a ostych. $\mathrm{K}$ matce, která pro ni byla přirozeně hlavní autoritou pokud jde o záležitosti praktického života nebo typické ženské záležitosti, měla patrně mnohem blíže; bylo to především citové pouto, které spojovalo dospívající dceru logicky více s matkou než s otcem

Máme-li shrnout nějakým způsobem témata, o nichž se pisatelka ve svých dopisech vyjadřuje, je nutno si uvědomit, že většina z nich se týká každodenního života, tak, jak se události odehrávaly den za dnem, jak dívka poznávala rodinu, dům (,,kancelár v prízemi domu“, ,di̊m je velmi hezký, celý šedý, ze strany zahrady pokrytý divokým vinem. Zahrada, kde je hodně bylinek a květin, není velká, ale je hezká ") a továrnu Podhajských (její popis viz výše), zvyklosti a činnosti rodiny, u níž žila, jak poznávala nejbližší hostivařské okolí, dopravu do centra města a s tím spojené aktivity (viz prohlídka historických míst, památek či významných budov v Praze, výlet na Karlštejn, návštěva výstav a divadel na jedné straně a návštěvy renomovaných obchodních center či obchodů nebo společenské návštěvy př́buzných Podhajských a známých rodiny Mazonových na straně druhé). Dívčiny denní činnosti byly, alespoň zpočátku, z velké části plánované, jak ze strany tatínka, pokud pobýval v Praze, tak rodinou Podhajských, u kterých bydlela. Jacqueline se zmiňuje o tom, že programovou náplň dní měla na starosti především mladá Anna Podhajská, která byla zjevně pověřena rodinou francouzské přítelkyni nejen „sestavit“ denní harmonogram (byl patrně členěn na dopoledne, odpoledne, popř. večer), ale také ji při jejích aktivitách doprovázet (pokud ji nezastoupil jiný člen rodiny Podhajských). Jak vyplynulo z dopisu z 10. záŕí, Jacqueline si na toto Annino př́lišné plánování i způsob, jakým si spolu prohlížely pražské památky, postěžovala matce (viz výše) ${ }^{91}$ Tady patrně svou roli hrálo nejen povahové založení obou dívek ${ }^{92}$ ale také ta skutečnost, že Anna daná místa a památky znala (viděla je už mnohokrát), a tak výklad o nich brala spíše jako rutinu a společenskou zdvořilost ukázat francouzské návštěvnici Prahy co nejvíce. Její francouzská př́telkyně je naopak viděla poprvé, byla jimi okouzlena a své dojmy a zážitky neměla možnost patřičně „strávit“. Teprve ke konci pobytu, když Jacqueline našla způsob, jak sama vyklouznout $\mathrm{z}$ domu a jak se nejlépe dostat do Prahy (řečeno laicky „když už se rozkoukala“ a věděla co a jak), si svůj denní program a s ním spojené cesty do Prahy víceméně režírovala sama; cítila se tak nepochybně o poznání svobodněji (i když se $\mathrm{v}$ korespondenci matce přiznává, že v Praze zabloudila: „prošla jsem se po Praze, trochu jsem se pak ztratila ve spleti malých starobylých uliček Starého Měst a vrátila se vlakem v pưl sedmé “93 a také zřejmě „, dospěleji“.

Svoji roli $\mathrm{v}$ přesunech $\mathrm{z}$ Hostivaře do Prahy hrála i vzdálenost Hostivaře a vnitřní Prahy a s tím spojená doprava. Dívky mohly využít př́ležitostně firemní auto p. Podhajského, které je zpravidla svezlo jen kus cesty, nebo jet vlakem z Hostivaře. Jacqueline se o cestování vlakem zmiňuje $\mathrm{v}$ dopisech na různých místech. Tak např. hned ve druhém dopise ze 7. záŕí čteme, že ,, cesta z Hostivaře do Prahy vlakem neni vůbec drahá: trvá puil hodiny a stoji 2 Kč 50 (stejně jako známka na dopis do ciziny, což je něco kolem 1.55 frankư “, v dopise 10. zárí píše, že „Praha je vlakem 20 minut odsud, ne vic ". A vlakové spojení často při

\footnotetext{
${ }^{89}$ Viz oslovování Jacqueline křestním jménem ze strany Podhajských, jež nebylo od začátku samozřejmostí, anebo Jacquelinino postesknutí nad nedostatkem soukromí a osobní volnosti (viz výše).

90 „,... j’ai bien regrette que tu ne fusses pas la pour voir tous ces admirables tableaux des maitres tchèques inconnus du Moyen Âge. “

${ }^{91}$ Dopis z 10. záŕí.

${ }^{92}$ Srov. dopis z 10. záríi: „Anna a Helena jsou stále milé a velice laskavé. Nejdřive jsem si myslela, že bych si mohla lépe rozumět s Annou, ale od třetího dne si víc rozumím s Helenou“ " a 15. zář́: „, Lida je velmi milá - ihned mnohem familiárnějš́ než Anna nebo dokonce Helena. “

${ }^{93}$ Dopis z 23. záŕí: , Je me suis promenée dans Prague, je me suis perdue un peu après dans un fouillis de vieilles petites rues pittoresques de la Vielle Ville, et je suis rentrée par le train de $6 h$ 1/2."
} 
psaní zdůrazňuje, jak u spojů z Hostivaře do Prahy (,,jela jsem vlakem v 1 h 12 "), tak při návratu z města (,,jel mi vlak za 5 minut 12h, a nemohla jsem ... “, „, vracela jsem se v pưl sedmé večer, jely jsme vlakem až ke skladišti Podhajských a vrátily se autem “, ,vlak v 11h55“ apod.). Skutečnost, že doprava Hostivař-Praha nebyla $\mathrm{v}$ polovině třicátých let pro obyvatele jednoduchá, dokládá zkušenost, kterou s ní Jacqueline měla; dá se s nadsázkou říci, že popis tzv. s ,,hostivařského tunelu“ v dopise 13. září je „minipříspěvkem“ $\mathrm{k}$ dějinám pražské dopravy viděné očima cizince.

Pražské památky mladou dívku nepochybně zaujaly z jejího popisu vyplývá, že si prohlédla všechny hlavní historické monumenty hlavního města. Viděla Karlův most, Staré Město s radnicí a orlojem, Týnský chrám, Židovský hřbitov, Klementinum, navštívila pochopitelně Pražský hrad, chrám sv. Víta i Valdštejnský palác a jeho zahradu. Praha na ni zapůsobila především svými věžemi (o ,stověžaté Praze“ patrně již dř́ve četla, vždyt' měla ,tlustou“ knihu o Praze...) a svými kostely. Jejich barokní architekturu a výzdobu interiérů však ocenit nedokázala. Dokážeme to pochopit, protože $\mathrm{s}$ barokní architekturou, sochařstvím a malírstvím toho typu, který viděla v Praze, se zjevně ve Francii nesetkala a fenomén ,českého baroka“ jí zrrejmě ještě nic neříkal. Nemůžeme se divit, že jí jako Francouzce byla bližší spíše gotická architektura, středověké artefakty a klasicistní umění, pro tuto románskou zemi tak typické. Vždyt' i francouzská historiografie a umělecká kritika považovala dlouho baroko za umělecký styl přechodového období, umělecky nezajímavý ${ }^{4}$ a již samotné slovo „baroque“ mělo pod dlouhou dobu ve francouzském prostředí pejorativní význam. Francouzské školství ostatně dávalo (a dodnes pravděpodobně někdy dává) při výuce větší prostor výkladům o klasicismu než o baroku, což je logické vzhledem k tomu, jakou roli tento umělecký styl sehrál v dějinách francouzské kultury (zejména pokud jde o literaturu a také architekturu, kde převládal spíše barokní klasicismus a typicky barokních malír̆u bychom ve Francii mnoho nenašli, na rozdíl od Itálie, Španělska či českých zemí). Francie, podobně jako další evropské státy (včetně Německa) znovuobjevuje barokní umění až na konci 19 . stoletíi ${ }^{95}$ a $\mathrm{k}$ oživení zájmu o tento umělecký sloh ve Francii pak dochází až ve třicátých letech minulého století $\mathrm{v}$ souvislosti s nástupem avantgardního umění (surrealismus se barokem značně umělecky inspiruje, nebot' oba umělecké styly sbližuje podobná poetika a podobné vidění reality). ${ }^{96}$ Svůj vliv na propagaci českého barokního umění ve Francii mají erudované práce bohemisty historika Victora-Luciena Tapié (1900-1974), jež však vycházejí později. ${ }^{97}$ Nelze mít tedy dospívající Jacqueline ovlivněné francouzským školstvím a tehdejším estetickým vkusem za zlé, že jí baroko jako umělecký styl bylo poněkud vzdálené, barokní výzdoba kostelů se jí zdála přehnaná anebo nevkusná. ${ }^{98} \mathrm{Na}$ druhou stranu i mezi francouzskými umělci byli tací, kterým se české baroko líbilo a kteří si jej zamilovali, zvláště v prŕípadě, když měli možnost se s ním seznámit př́imo na místě. Necháme-li stranou osobnost básníka a dramatika Paula Claudela (1868-1955), který před první světovou válkou strávil v Praze tři roky jako konzul a o němž je známo, že to bylo právě pražské baroko, které jej doslova okouzlilo a stalo se spolu s barokní španělskou literaturou mocným inspiračním zdrojem jeho katolicky laděné tvorby, můžeme zmínit jiné dva francouzské literáty, kteří ve 20. a 30. letech zavítali do Prahy a o svých dojmech nám zanechali svá svědectví. Prvním z nich byl spisovatel Romain Rolland (1866-1944), který navštívil Prahu se svou sestrou na jaře roku 1924 na pozvání T. G. Masaryka a jemuž byl zasvěceným průvodcem po Praze známý historik prof. Václav Vilém Štech. „Rollandìv pražský program byl bohatý", píše P. Kneidl. ${ }^{99}$ Spisovatel si do svého deníku o Praze, kterou porovnává s Ř́mem, napsal tato slova: „, Obdivuhodná zahrada premonstrátů, která mi připomíná Janikukus a řimské vily. Uprostřed těchto krásných zahrad, těchto do vi̊ně rozkvetlých stromü, těchto barokních kosteli̊, těchto starých, nahoru a dolì se vlnících ulic a těchto pružných pahorků stále myslím na Řim. Praha je hlavním městem baroka: vládne v ní bez soupeře. "100 Tím druhým návštěvníkem byl Francouz André Salmon (1881-1969), básník, prozaik a teoretik avantgardního umění zabývající se kubismem, který byl již ovlivněn moderními myšlenkovými směry, včetně nastupující barokně laděné surrealistické estetiky. Při své návštěvě Prahy u prŕležitosti výstavy École de Paris v Obecním domě v roce $1931^{101}$ strávil ve městě několik dní a Prahou byl velice nadšen. Kromě moderní architektury a moderních ulic, krásy pražských zahrad, města kypícího životem, plného vůní, hudby i krásných dívek, se mu líbí také pražské historické památky, nejen ty gotické. „Ó Karlưv most! Ó Prašná bráno! A všechen onen barok

\footnotetext{
${ }^{94}$ Francie nepřejala (až na výjimky) baroko italského typu, ale vyvíjela vlastní oficiální umění, jehož cílem byla oslava královské moci a monarchistického státu. Baroko, které ve Francii sloužilo k upevnění moci panovníka, se transformovalo do podoby barokního klasicismu hledajícího inspiraci v antických předlohách. Odborníci se domnívají, že klasicistní styl odpovídal francouzskému smyslu pro přehlednost a eleganci, a proto se nejvíce prosadil právě ve Francii.

${ }^{95}$ Jako jeden z prvních autorů dokázal ocenit vizuální znaky barokního stylu švýcarský historik umění Heinrich Wölfflin (1864-1945), viz jeho práce o zrodu italského baroka Renaissance und Barock, která vyšla v roce 1888 v Mnichově.

${ }^{96}$ Viz vyjádření „Picasso, surréaliste baroque“. Srov. VLASIE 2013.

${ }^{97}$ Zejm. práce z roku 1938 (L'Art religieux baroque en Tchéco-Slovaquie ) anebo z roku 1957 (Baroque et Classicisme). Specifičnost českého literárního i výtvarného baroka vzhledem k evropskému baroku zdůrazñují práce Zd. Kalisty (České baroko. Studie, texty, poznámky. Praha 1941 aj.) a Václava Černého (srov. ČERNÝ 1996 a další jeho studie, dostupné i ve francouzském jazyku). Srov. též sborník konferenčních příspěvků editovaný M. Kopeckým z roku 1968 O barokní kultuře (tam zejm. stati Josefa Válka a Jaromíra Neumanna). Samozřejmě dnešní francouzská historiografie a literární věda tuto specifičnost nejen uznává, ale také se jí intenzívně badatelsky věnuje - viz práce Oliviera Chalina nebo E. Ducreux).

${ }^{98}$ Je otázkou, zda mohla znát knihu Arne Nováka o barokní Praze (česky vyšla roku 1915, francouzsky 1920) - viz NOVÁK 1915 , NOVÁK 1920.

${ }^{99}$ KNEIDL 2005, s. 266.

100 Tamtéž. U Rollanda zjevně hrála roli jeho láska k římské barokní architektuře a Římu.

${ }^{101}$ Salmon napsal předmluvu k výstavnímu katalogu a přednesl několik přednášek o francouzském umění a literatuře.
} 
po oné gotice! Oni svatí ve dvorních hávech, tak milostně zahalení jezuity"!102 Skutečnost, že Jacqueline dávala přednost středověkému umění, a to jak před „křiklavým barokem “, tak také před současným uměním, které ji neoslovilo, dokazuje mj. její kritika moderních vitráží v chrámu sv. Víta nebo návštěva holešovické Moderní galerie, kam ji doprovázela slečna Podhajská, a její hodnocení moderních ,, hrozných obrazů“. ,,Je to nanášení barvy vrstva na vrstvu a je velmi těžké najit v tom nějaké tvary a uhodnout, co to asi znázorňuje. " Při návštěvě Universitní knihovny v Klementinu (dnes Národní knihovny) prošla nejen všechny čtenářské a výpůjční sály, ale prohlédla si rovněž historické části; nejvíc se jí líbilo v muzeu knihovny, kde mohla opět obdivovat středověké umění (,, toute la partie consacrée au Moyen Age est admirable"), zejména středověké obrazy, miniatury a piety nebo dřevěné sochy s působivě vyřezávanými výrazy v obličeji, do nejmenšího detailu propracovanými. Pozoruhodný $\mathrm{v}$ této souvislosti je její popis exkurze do nedávno postavených pavilonů areálu tzv. Pražských škol v Dejvicích, i když bohužel o této výjimečné stavbě toho mnoho mamince nenapsala. Funkcionalistický styl budov sice hodnotí prrívlastkem ,, archimoderne “ a o areálu se vyjadřuje, že ji překvapil svým nečekaným vzhledem (,, aspect tout a fait inattendu“) a že uvnitř budov je velmi př́ijemně, protože je tam hodně světla, ale to je všechno. Silným zážitkem pro ni byla návštěva Petřína, výstup na petřínskou rozhlednu a procházka petřínskými zahradami. Anna jí ukázala sochu Karla Hynka Máchy, dívky se svezly lanovkou, vystoupily na věž, navštívily bludiště a prohlédly si petrrínské diorama Bitvy Pražanů se Švédy. Upřímně, a tak trochu zahanbeně, přiznala, že když vystoupala na „pražskou Eiffelovku“, měla by vylézt i na Eiffelovu věž v Paříži, na níž ještě nikdy nebyla (uvědomila si, že cizincům, v tomto případě Anně, kteří tento ikonický symbol Paříže obdivují, je asi nepochopitelné, že tak ještě nikdy neučinila).

Jacqueline při procházkách Prahou však nevnímala jen samotné památky, ale zaujaly ji též etnografické zvláštnosti, s nimiž se střetávala na ulici nebo které viděla v národopisných sbírkách (srov. její návštěvu Národopisného muzea a jeho popis v dopise ze 7. záŕí, lidové zvyky a oblečení, lidové výšivky - ,Neviděla jsem venkovany v krojích, ne vic než ve Francii, ale všechny venkovanky nosi na hlavě velký šátek, často hezky vyšívaný. "103). Obdivovala módu inspirovanou lidovým uměním (srov. ony „užasné“ vyšívané šaty, o jejichž koupi i krejčovské úpravě se podrobně rozepisuje v dopisech z 23. a 24. záŕí), i lidový hudební folklór (srov. zmínku o tom, že paní Podhajská hrála a zpívala lidové písně apod.). Samostatnou kapitolou je pak nákup typicky českých a slovenských suvenýrů, především krojovaných panenek. Ty nakoupila na „Pražském veletrhu“, spolu s dalšími lidovými suvenýry a další pak ještě v jednom obchodě (viz dopis ze 7. záŕí). Palác Pražských vzorkových veletrhů (P.V.V.) postavený v letech 1924-1929, dnešní Veletržní palác, ${ }^{104}$ byl v té době významnou platformou prezentující domácí i zahraniční firmy a propagující československé výrobky (Jacqueline se zmiňuje o českém skle), důležitou pro rozvoj mezinárodní obchodní spolupráce. Svědčí o tom koneckonců četné dobové dokumenty a zprávy v tehdejším tisku. Obdivně a s trochou závisti se o Paláci, významné stavbě raného funkcionalismu u nás a jedné z nejmohutnějších konstruktivistických budov v Praze, vyjádřil teoretik moderní architektury, podle jehož ideálů byl postaven, slavný švýcarsko-francouzský architekt a malír Le Corbusier (1887-1965). Ten se stýkal s českými avantgardními umělci, mezi nimiž měl řadu obdivovatelů i kritiků, a Prahu a Československo navštívil celkem čtyřikrát. ${ }^{105}$ Při své třetí návštěvě Prahy v říjnu roku 1928 v rozhovoru s Karlem Teigem uveřejněném v Rozpravách Aventina tuto konstruktivistickou stavbu z hlediska architektonického ocenil takto: „Opravdovým záźitkem byla pro mne prohlidka první budovy P.V.V. [Pražských vzorkových veletrhů]. První dojem obrovského paláce je impozantní. O mém návrhu na palác S. N. [Společnosti národů] v Ženevě se tvrdilo, že je nerealizovatelný. - Pražské Veletrhy prakticky vyvracejí takové námitky: jsem št’asten, že v Praze je realizován obrovský palác, architektura pojatá v tom duchu, jak ji propaguji... " Přes menší námitky týkající se půdorysu a architektonického ztvárnění stavby řekl, že blahopřeje Praze a zdejší architektuře, že „,může realizovat tak grandiózní stavební dílo. “106 Pražské obchody i zboží prodávané na Pražských vzorkových veletrzích měly tehdy ve světě velké renomé, kvalitou a cenou se mohly rovnat nabídce velkých pařížských obchodních center. A Jacquelinin popis několika nákupů bot a střevíčků a punčochového zboží v obchodním domě Bat'a a její pochvalné vyjádření o jejich ceně a kvalitě je toho výmluvným dobovým svědectvím.

Fenomén české kuchyně, česká jídla a způsoby stravování - to je další zajímavé téma, k němuž se mladá dívka vyjadřuje. Rodina Podhajských se evidentně snažila, aby dívka ochutnala některá typicky česká jídla, takže Jacqueline jedla buchty, švestkové knedlíky i ,knedliky s masem “ (tedy vepřovou se zelím). A Podhajští byli rádi, když jí chutnalo (viz dopis z 15. záŕí). Matce se také zmiňuje o tom, že u Podhajských nejsou obědy a večeře tak bohaté a netrvají tak dlouho jako ve Francii, ale že je zvykem dopoledne i odpoledne svačit (dva krajíce tmavého chleba se slaným máslem

${ }^{102}$ Viz KNEIDL 2005, s. 307.

103 „J'ai n'ai pas vu de paysans en costume - pas plus qu'en France, mais toutes les paysannes portent sur la tête le grand mouchoir, souvent joliment brodé. “Dopis ze 7. zář́í.

${ }^{104}$ K historii Veletržního paláce blíže viz např. SEDLÁKOVÁ-POTƯČEK 2014 A FIALOVÁ 2016. Veletržní palác byl, částečně, dokončen k 10. výročí vzniku Československa a první veletrh se konal již v září 1928. Při té příležitosti byla také poprvé veřejnosti představena Slovanská epopej Alfonse Muchy. Celá budova sloužila však nejen jako výstavní veletržní prostor (trhy se konaly pravidelně na jaře a na podzim), ale byla v něm i řada restaurací, největší pražské kino a v jeho malé dvoraně se konaly také výstavy umění. Veletržní palác fungoval v podstatě až do roku 1951, kdy byly Pražské vzorkové veletrhy zrušeny.

${ }^{105} \mathrm{~K}$ jeho osobě viz LE CORBUSIERa, LE CORBUSIERb, pražským pobytům a kontaktům Le Corbusiera s Teigem a českou avantgardou srov. MICHALOVÁ 2016. Ke kontaktům Teiga, který byl přítelem (a částečně i kritikem) Le Corbusiera, ve světle osobní Teigovy knihovny srov. KAŠPAROVÁ - KONEČNÁ 2016.

${ }^{106}$ Viz TEIGE 1928-1929, KNEIDL 2005, s. 233-234. Též rozhovor Le Corbusiera s A. Hoffmeisterem, viz HOFFMEISTER 1988. 
a k tomu ovoce). Dnes se možná usmíváme, když čteme, že ji v Čechách překvapuje obliba tmavého chleba, kterému se dává přednost před francouzským bílým chlebem (v dnešní době ,, baguettes “ a ,,ficelles “ lze koupit běžně i u nás a jejich obliba je značná). Záliba ve sběru a zpracování hub byla společná jak rodině Podhajských, tak Jacqueline a rodině Mazonových. Nicméně Čechy, kteří mají houbaření přímo v genech, předčí málokterý národ. Jacqueline měla však se sběrem hub zjevně bohaté zkušenosti ve Francii (s maminkou tuto zálibu, jak se zdá, sdílela), znala dobře jednotlivé druhy hub, některé dokonce lépe než teta „Klemi“, vyhlášená znalkyně. Houbové omáčky, které vzhledem k nebývalé úrodě hub toho roku měli u Podhajských velmi často, jí zřejmě velice chutnaly. Na doporučení tety „Klemi“ navštívila i výstavu hub nedaleko bydliště Podhajských. Ostatně houby viděla také jako model pro hodinu kreslení ve škole, kam ji slečna „Klemi“ Podhajská pozvala, aby si udělala představu o výuce na pražské dívčí škole, kde byla ředitelkou...

$\mathrm{V}$ korespondenci najdeme také pasáže věnované popisu divadla a společenských návštěv. Společně s Annou měla možnost shlédnout Dvořákovu operu Rusalka v Národním divadle a spolu s tatínkem, Annou a Helenou viděla ve Vinohradském divadle napoleonskou veselohru lehčího charakteru „Císařùv dvojník“, z pera tehdejšího nepř́liš známého českého autora, lékaře chirurgického oddělení pražské vinohradské nemocnice, Jiř́ího Vernera, ${ }^{107}$ která měla svou premiéru právě v roce 1934. Pozvání na oběd či večeři bylo v té době samozrejmou společenskou konvencí a př́ležitostí k přátelským rozhovorům a setkání se zajímavými lidmi. $\mathrm{S}$ tatínkem zašli na odpolední návštěvu $\mathrm{k}$ paní Madeleine Vokounové, knihovnici Francouzského institutu Ernesta Denise v Praze, sama Jacqueline navštívila př́telkyni Podhajských paní Ludmilu Schieszlovou (její syn Jan si později vzal nejmladší dceru Podhajských Helenu), kde se setkala mimo jiné s další významnou postavou pražské a pařížské intelektuální společnosti paní Scherrer-Dolgoroukovou. Navštívila také rodinu profesora Murka, známého slavisty žijícího a působícího v Praze, a konečně v závěru svého pobytu také manžele Boženu a Hanuše Jelínkovy, s nimiž se Mazonovi dobře znali a u nichž se setkala s dopisovatelkou Národních listi̊ v Paříži, s největší pravděpodobností novinářkou Sísovou (Jacqueline o ní mluví jako o paní, jejíž jméno zapomněla). S manželi Jelínkovými Jacqueline udržovala kontakt i v dospělosti (po smrti Hanuše Jelínka pak s jeho paní Boženou Jelínkovou). ${ }^{108}$

Pokud jde o módu, Jacqueline se o ni jako typická Francouzka pochopitelně zajímala (z dopisů je to ostatně víc než patrné), zajímala ji především typicky česká a slovenská lidová oděvní tvorba (různé výšivky, krajky a šaty jimi zdobené). Ve svém oblékání (jak při návštěvě divadla nebo i při sportu) byla však mnohem konzervativnější a usedlejší než její české přítelkyně. Ty i do divadla chodily oblečeny prostěji, dá se říci, moderněji. Jacqueline píše, že si s sebou přivezla řadu svátečních šatů, ale že si některé raději neoblékla, aby se př́liš neodlišovala od svých českých vrstevnic. Mladé dívky Podhajských jsou sportovně založeny, kromě stolních her (karty, dáma) pravidelně hrají tenis, volejbal, opalují se v plavkách, zatímco Francouzka nosí i v horku dlouhé punčochy (,,v tomto vedru tady žádná z divek nenosí dlouhé punčochy /jedině když jdeme do města/ a stále se diví, když vidí, že je nosím v domě, na zahradě a na tenise "109) a tenis hraje výjimečně, raději jej jenom sleduje, protože sport ji unavuje. Pražská móda nebyla nikterak upjatá, mladé pražské dívky chodily v létě zřejmě víc odhaleny, než jak byla Jacqueline zvyklá. Rozdíly mezi jejím způsobem oblékání a oblékáním pražských dívek byly evidentní. Mladá děvčata Podhajských trendy pražské módy jistě sledovala a podle toho volila pro různé situace různý způsob oblékání. Móda to byla jednoduchá, praktická, sportovní i slavnostní, v létě vzdušná a př́ijemná a mužskému oku lahodící. Dovolíme si opět citovat z dojmů André Salmona, který byl všímavým pozorovatelem pražského života, zejména dívek. ,.V Praze jsou všechna dvacetiletá děvčata hezká. [...] Slečny ve své nevinnosti libuji si v krátkých bilých ponožkách, a pevné nahé nohy se ztrácejí vysoko v krepdešínu. [...] Na vodě, uprostřed města, nejhrdějši sportovní mládež. Nad vaši pečenou husou nebo knedličkovou polévkou mihne se zčista jasna červený, bílý, svètlý nebo modrý, bílý a hnědý šíp. Je to dvacetiletá plavkyné, skákajicí do Vltavy z terasy restaurantu. " 110

Jacqueline byla intelektuálně vyspělá dívka s humanitními zájmy, sečtělá, jazyků znalá; ovládala němčinu, hovořila obstojně česky a v jazycích se stále zdokonalovala.

V Praze si český jazyk určitě zdokonalila. Pobyt Francouzky v české rodině byl z hlediska jazykového přínosem jak pro ni, tak pro mladé Podhajské. Jacqueline spolu s Annou nebo Helenou konverzovaly česky i francouzsky. Procvičovaly si jak češtinu, tak i francouzštinu zábavnou formou - např. při procházce hostivařským parkem se učily pojmenovat v obou jazycích stromy, houby, květiny a zvírata a také četbou dětské literatury. Pravidelně si četly v českých knížkách (srov. společnou četbu Bibi, Erbenových pohádek) na zahradě domu a následné si obsah přečteného převypravovaly vlastními slovy. S Helenou si Jacqueline opakovala českou gramatiku a na radu Heleny a Lídy koupila tatínkovi Čapkovy cestopisy (Italské listy a Obrázky z Holandska), v nichž si četla i ona a které se jí velmi líbily. Dokonce si na př́kladu Čapkova slovníku učila znát a vyslovovat superlativy českých přívlastků (srov. výše citovaný text: „Učím se znát postupně všechna ta adjektiva, jež pronesena určitým zpưsobem, s di̊razem na první slabiku, jsou výrazem

\footnotetext{
${ }^{107}$ Srov. AMATÉRSKÉ DIVADLO (heslo k jeho osobě a dílu).

${ }^{108}$ Dokladem toho jsou dopisy ve fondu Mazon v archivu pařǐžského Institutu slovanských studií dokládající kontakty rodiny Jelínkových a Mazonových, korespondence Hanuše Jelínka s André Mazonem v Literárním archivu Památníku národního písemnictví a knihy, které si vzájemně jednotliví členové rodin darovali. Viz též KAŠPAROVÁ 2020, s. 16-19 a PROVENIO DATABÁZE http://provenio.net/authorities/58581. Ke korespondenci Jelínka s Mazonovými viz BADATELNA.EU Literární archiv Památníku národního písemnictví, fond Hanuš Jelínek. Dostupné z: http://www.badatelna.eu/fond/2966/rejstrik/?q=Mazon\& $t=0$.

109 „par cette chaleur, ici, aucune des jeunes filles ne porte de bas longs (sauf quand on va en ville), et elles s'étonnent toujours de me voir en porter dans la maison, dans le jardin et du tennis. " Dopis z 15. záŕí.

${ }^{110}$ Viz KNEIDL 2005, s. 307.
} 
nejvyššiho obdivu“). Karel Čapek patřil zjevně k jejím oblíbeným autorům, dokonce radila dívkám Podhajských, co si z děl Karla Čapka mají přečíst! Lídě doporučila Čapkův Zahradnikưv rok, který měla již na rozdíl od Lídy přečtený a z něhož jí citovala úryvky. ${ }^{111} \mathrm{O}$ tom, že Jacqueline česky uměla docela dobře, svědčí také to, že byla schopna číst Čapkovo R.U.R v češtině, a také to, že její schopnosti hovořit česky pochválili manželé Jelínkovi, což nebyl patrně jen zdvořilostní kompliment. Jacqueline používala češtinu a některé české výrazy i v písemné podobě. Ve francouzsky psaných dopisech matce najdeme četná česká slova, někdy ve fonetickém přepisu a s interpunkcí, v nichž doslova „slyšíme“ francouzskou výslovnost - „Hostivár̆“", „Pařiž“", „knedliky“, „Lidda“, ,veverkí“, ,Narodopisnimuseum“, „Russalka“, „Hlavni Pošta“, ,,Théâtre Vinohradsky“, u některých českých názvů doplňovala francouzský člen - „le Hrad“, „la Prašna brána“ „la Stromovka“, „l'Obecny Dům “ (naproti tomu korektně „,Národní divadlo “, „Národní Listy “, „, Týn “), u jiných zase český ekvivalent přidala k výrazu ve francouzštině - , ,St Guy (sv. Výt) “, ,jouer, tj. faire des balles, česky pinkáti“, „, la vallée (üdoly) “, „,Mistigris en tchèque Černé Petr", ,, le bureau (le Kanceláře) “. A jméno malého chlapečka Evženka najdeme dokonce v roztomilé česko-francouzské podobě - ,podivat se na Evgének“! Užití bohemismů $\mathrm{v}$ korespondenci matce tak jen dokresluje to, do jaké míry vnímala a doslova do sebe „nasávala“ českou realitu, která ji obklopovala. Ve znalosti českého jazyka dělala určitě velké pokroky a čeština u ní v době pražského pobytu dokonce vytlačovala němčinu, i když německy mluvila také zjevně dobře (srov. její kritiku slabých znalostí německé gramatiky u českých žaček kvarty při návštěvě školy). Matce v dopise ze 7. zárí píše: ,Ale také mám velmi ráda, když všude kolem sebe slyším mluvit česky. Když ted' chci říct větu německy, je to čeština, která se mi vybaví. "112

\section{Závěr}

Francouzská korespondence námi rozebraná představuje drobný historický bohemikální dokument přibližující Prahu, pražskou ekonomiku, kulturu, dopravu i život jejích obyvatel v roce 1934. Máme před sebou obraz Prahy viděný očima šestnáctileté Francouzky z intelektuální rodiny známého francouzského bohemisty a slavisty André Mazona. Jeho dcera Jacqueline Mazonová se stala později rovněž bohemistkou a uznávanou znalkyní české kultury a také velkou přítelkyní českého národa, jak to dokazuje její pozdější životní i profesní kariéra. ${ }^{113}$

Tento obraz je pochopitelně limitován věkem, vzděláním, celkovým osobním profilem pisatelky, jejím rodinným zázemím, společenským prostředím, v němž se pohybovala, a pochopitelně dobou, kdy vznikl. Osobní korespondence z pera mladé francouzské intelektuálky představuje nejen neformální výpověd’ o ní samotné a o osobách jí blízkých, ale dává také nahlédnout do každodenního života pražské rodiny z vyšší společenské vrstvy 30 . let 20. století; v neposlední řadě pak přináší dokonce řadu cenných a zajímavých postřehů týkajících se ekonomické a kulturní situace Prahy. Je nicméně škoda, že nemáme $\mathrm{k}$ dispozici doplňující korespondenci dalších zainteresovaných osob - matky a otce (obraz tohoto pražského pobytu z pera dospívající Francouzky by tak nabyl nepochybně bohatší a komplexnější podoby).

Soubor dopisů Francouzky Jacqueline Mazonové představuje svým způsobem ojedinělý a výjimečný dokument, jistý druh deníku ve formě dopisů. Jacquelininy osobní deníkové zápisky zachycují české reálie autenticky a bezprostředně, místy dokonce bez jakékoliv autocenzury. V mnohém potvrzují zkušenosti jiných návštěvníků-cizinců, ale v některých ohledech je doplňují a obohacují. Výpověd' mladé dospívající francouzské dívky, budoucí bohemistky, má i přes svůj osobní a intimní charakter silnou vypovídající hodnotu. Dopisy Jacqueline Mazonové představují důležitý kamínek do mozaiky francouzsko-českých vztahů a problematiky „francouzského pohledu“ na českou realitu a mentalitu („Češi očima Francouzư“), a to zejména z hlediska gendrového a sociologicko-psychologického. V budoucnu bude určitě zajímavé a užitečné srovnat tento informační pramen s jinými dochovanými dobovými dokumenty obdobného charakteru, at' již rukopisnými nebo tištěnými, z pera frankofonních či jinojazyčných pisatelů dívčina věku, pokud existují (zatím nám není známo, že by bylo k dispozici jiné podobné rukopisné dobové svědectví bohemikálního charakteru, jejímž autorem je francouzská dívka jejího věku a vzdělání). To je však již úkol přesahující téma našeho příspěvku.

\section{Prameny:}

ARCHIVES IES MAZONOVÁ: Archives Institut d'études slaves de Paris, fond André Mazon - korespondence Jacqueline Mazonové a Jeanne Roche-Mazonové ( 9 dopisů Jacqueline psaných matce z Prahy 3. 9. - 27. 9. 1934, 3 dopisy Jacqueline psané matce psané z Paříže 29., 31. 9. a 15. 10. 1934, 1 dopis Anny Podhajské Jacqueline Mazonové z 11. 1. 1935).

\section{Literatura a elektronické zdroje:}

AMATÉRSKÉ DIVADLO: Databáze českého amatérského divadla [online]. Osobnosti. VERNER, Jiří, MUDr., dramatik, Praha [cit. 29. 1. 2021]. Dostupné z: https://www. amaterskedivadlo.cz/main.php?data $=$ osobnost\&id $=6187$

BADATELNA. EU: Badatelna.eu pamétové instituce on-line [cit. 29. 1. 2021]. Dostupné z: http://www.badatelna.eu BDČZ SMIDAK: Smidak, Emil F., 1910-2003 [online]. BDČZ. Bibliografie dějin Českých zemí [cit. 29. 1.

\footnotetext{
111 Je otázka, zda jej četla česky (poprvé vyšel roku 1929), nebo ve francouzském překladu z roku 1933 (L’année du jardinier).

112 ,Mais j'aime beaucoup aussi entendre parler tchèque partout autour de moi. Si maintenant je cherche une phrase allemande, c'est le tchèque qui vient. “

113 KAŠPAROVÁ 2020, s. 16-19. Jacqueline Mazonová je mj. autorkou výboru textu z české literatury, čítanky Lectures tchèques. Avec commentaire et lexique par Jacqueline Mazon vydané roku 1944 a autorkou francouzského překladu pohádek Jiřího Mahena Contes tchèques z roku 1945 (srov. Tamtéž, s. 17-18).
} 
2021]. Dostupné z: https://biblio.hiu.cas.cz/records/ 1be6a52a-1bb6-4558-984d-5ccf7569b987

BERNÝ 2019: BERNÝ, Lukáš. Bio Sokol - první kino v Hostivaři. Ze života v Horních Měcholupech a Hostivaři. 16. Č́st [online]. Hlasatel. Zpravodaj městské části Praha 15, 25/2019, č. 5, s. 20-21 [cit. 29. 1. 2021]. Dostupné z: https://www.lukasberny.cz/wp-content/uploads/2019/12/ Hlasatel-2019-05-Bio-Sokol.pdf

BREUILLARD 2011: Breuillard Jean. Mazon linguiste. In: Revue des études slaves, tome 82, fascicule 1, 2011. André Mazon et les études slaves, sous la direction de Pierre Gonneau. s. 11-54.

ČERNÝ 1996: ČERNÝ, Václav. Až do předsíně nebes. Čtrnáct studií o baroku našem i cizím. Praha: Mladá fronta, 1996.

DRVOTA 2012: DRVOTA, Jan. Průmyslová zóna v Hostivaři (1918-1960) [online]. Praha 2012. Bakalářská práce. Univerzita Karlova, Filozofická fakulta, Ústav hospodářských a sociálních dějin, s. 35-39. [Cit. 29. 1. 2021]. Dostupné z:

https://is.cuni.cz/webapps/zzp/detail/106498/

DW DOSSIERWEB 2015: Hinko Pogacnik: Un ejemplo pujante de la fe en el futuro [online]. DW DossierWeb en mayo 18, 2015 [cit. 29. 1. 2021]. Dostupné z: https://www.dossierweb.com.ar/ hinko-pogacnik-un-ejemplo-pujante-de-la-fe-en-el-futuro/

FDB.CZ SÍSOVÁ: Miloslava Sísová [online]. FDb.cz Filmová databáze [cit. 29. 1. 2021]. Dostupné z: https:// www.fdb.cz/lidi-zivotopis-biografie/406490-milada-sisova. html

FIALOVÁ 2016: FIALOVÁ, Barbora. Funkcionalismus a jeho dědictví v Praze 7 [online]. Stampsy [cit. 29. 1. 2021]. Dostupné z: https://stampsy.com/stamp/25216

GILLAR 1935: GILLAR, Jan. Francouzské školy v PrazeDejvicích. Stavitel 1935, č. 2, s. 17-32.

GOLIS 2018: GOLIS, Ondřej. Je to jen dovršení zkázy, bude se bourat, rríká o hořící hale v Hostivaři pravnuk továrníka, který ji postavil [online]. iRozhlas.cz, 9. 5. 2018 [cit. 29. 1. 2021]. Dostupné z:

https://www.irozhlas.cz/zpravy-domov/pozar-hostivartovarna_1805091345_ogo

HAVLÍKOVÁ 2002: HAVLÍKOVÁ, Lubomíra. Mezinárodní sympozium Matija Murko Osobnost a dílo [online]. Akademický bulletin 2002, č. 5 [cit. 29. 1. 2021]. Dostupné z: http://abicko.avcr.cz/miranda2/m2/archiv/2002/5/obsah/mezinarodni-sympozium-matija-murko-osobnost-a-dilo.html

HNILICA 2012: HNILICA, Jiří. France dans la formation des élites Tchécoslovaques (1900-1950) [online]. Praha, 2012. Dizertační práce. Univerzita Karlova, Pedagogická fakulta [cit. 29. 1. 2021]. Dostupné z: https://dspace.cuni.cz/ handle/20.500.11956/45166

HOFFMEISTER 1988: HOFFMEISTER, Adolf. Aperitif s Le Corbusierem. In: Podoby \& predobrazy. Praha: Československý spisovatel 1988, s. 325-334.

HOŘEJŠ 2005a: HOŘEJŠ, Miloš. Vývoj organizačních forem čs. průmyslu obráběcích a tvářecích strojů: továrny strojírenské techniky a předchůdci. In: FOLTA, Jaroslav HOŘEJŠ, Miloš (edd.). Továrny strojírenské techniky v 19. a 20. století. Praha: Společnost pro dějiny věd a techniky, 2005, s. 5-26.

HOŘEJŠ 2005b: HOŘEJŠ, Miloš. Studijní dráha Ing. Otakara Podhájského, pozdějšího továrníka v Hostivaři. In: Rozpravy Národního technického muzea 193, řada Dějiny vědy a techniky 13, 2005, s. 15-25.

HOŘEJŠ 2006: HOŘEJŠÍ, Miloš. Cesty za vzděláním a praxí konce 19. a začátku století 20. - na př́íkladu pětice podnikatelů ve strojírenském průmyslu [online]. In: Rozpravy Národního technického muzea v Praze, sv. 200, rada Déjiny vědy a techniky, sv. 14. Praha: Národní technické muzeum, 2006 [cit. 29. 1. 2021]. Dostupné z: http://www.ntm.cz/data/ veda-a-vyzkum/publikace/rozpravy_ntm_200.pdf

CHROBÁK 2007: Chrobák, Tomáš. André Mazon - intelektuál ve válce. In: Slovanské historické studie 32. Miroslavu Šestákovi a Miroslavu Tejchmanovi k sedmdesátinám. Praha: Historický ústav AV ČR, 2007, s. 341-350.

KAŠPAROVÁ 2020: KAŠPAROVÁ, Jaroslava. Mezi Prahou a Paříží. Neznámé a málo známé „hrdinky“ česko-francouzského kulturního světa první poloviny 20. století. Acta Musei Nationalis Pragae - Historia litterarum 65, 2020, č. 3-4, s. 5-23.

KAŠPAROVÁ - KONEČNÁ 2016: KAŠPAROVÁ, Jaroslava - KONEČNÁ, Jana. Francouzské provenience v knihovně kritika a teoretika umění Karla Teiga v knihovně Národního muzea. Sborník Národního muzea v Praze, řada C-Literární historie 61, 2016, č. 1-2, s. 83-92.

KAŠPAROVÁ - MĚŘIČKA 2019: KAŠPAROVÁ, Jaroslava - MĚŘIČKA, Matěj. Virtuální rekonstrukce rozptýlených provenienčně bohemikálních knižních celků v tuzemských i zahraničních knihovnách - prozatímní výsledky výzkumu. Acta Musei Nationalis Pragae - Historia litterarum 64, 2019, č. 3-4, s. 63-64.

KNEIDL 2005: KNEIDL, Pravoslav. Setkání s Prahou. Vztahy mezi městem a zahraničními umělci a vědci od Francesca Petrarcy po Allena Ginsberga. Knihu připravili k vydání Jarmila Schreiberová, Miloslav Kopecký a Hugo Schreiber. Praha: Perseus 2005, s. 232-234.

KONÁRKOVÁ 2013: KONÁRKOVÁ, Marika. Devět tisíc šuplíků obsahuje údaje téměř všech obyvatel ČR [online]. Novinky cz, 15. 11. 2013 [cit. 29. 1. 2021]. Dostupné z: https://www.novinky.cz/domaci/clanek/devet-tisic-supliku-obsahuje-udaje-temer-vsech-obyvatel-cr-209020

KROK 2020: Francouzské stopy na Hané [online]. Krok. Kulturní Revue Olomouckého kraje 17, 2020, č. 4 [cit. 29. 1. 2021]. Dostupné z:

https://www.vkol.cz/uploads/revue/71/doc/krok-4-2020$w w w-1 . p d f$

KUČERA RKP 2020: KUČERA, Martin. Francouzský jazyk a kultura v Olomouci (rukopis připravený do tisku, Olomouc 2020).

LE CORBUSIERa: Le Corbusier [online]. StavbaWeb [cit. 29. 1. 2021]. Dostupné z: https://www.stavbaweb.cz/le-corbusier-8296/clanek.html

LE CORBUSIERb: Le Corbusier [online]. Archiweb [cit. 29. 1. 2021]. Dostupné z: https://www.archiweb.cz/ le-corbusier

LIDOVÉ NOVINY 1934: Pražské vzorkové veletrhy [online]. Lidové noviny, sobota 1. 9. 1934, s. 16 [cit. 
29. 1. 2021]. Dostupné z: https://www.lidovenoviny.cz/file. aspx? $n=L N-N O V I N Y \& d=01.09 .1934 \& e=L N 1 \& p=L N A 016$ LUKEŠ SKRYTÉ POKLADY 2018: LUKEŠ, Zdeněk. Skryté poklady architektury - 9. Díl - Areál tzv. Francouzských škol [online]. TV ARCHITECT COM 2018 [cit. 29. 1. 2021]. Dostupné z: https://www.tvarchitect.com/ video/s-p-a-9-areal-tzv-francouzskych-skol/

MARÈS 2011: MARÈS, Antoine. André Mazon, un slaviste au XXe siècle. Profil politique d'un savant [online]. In: Revue des études slaves, tome 82, fascicule 1, 2011, s. 69-94 [cit. 29. 1. 2021]. Dostupné z: https://www.persee. fr/doc/slave_0080-2557_2011_num_82_1_8000

MICHALOVÁ 2016: MICHALOVÁ, Rea. Karel Teige. Kapitán avantgardy. Praha: Kant 2016 (v kap. Rád konstrukce a zrnko bláznovství, s. 228-237; fotopř́loha s. 42-43).

MIKLOŠKO 2009: MIKLOŠKO, Jozef. Emil Smidak, zabudnutý genius [online]. SME blog 2. 7. 2009 [cit. 29. 1. 2021]. Dostupné z: https://jozefmiklosko.blog.sme. sk/c/198561/Emil-Smidak-zabudnuty-genius.html

MÍSTOPIS HOSTIVǍ̌: Hostivař [online]. Místopis České republiky. Praha. Povodi Botiče. Hostivař [cit. 29. 1. 2021]. Dostupné z:

http://www.mistopis.eu/mistopiscr/praha/praha15/hostivar. htm

MYHERITAGE: MyHeritage [online]. Family history website [cit. 29. 1. 2021]. Dostupné z: https://www.myheritage.cz

NOSKOVÁ 2020: NOSKOVÁ, Milena. Claude Kastler představitel slavistiky a propagátor českého jazyka ve Francii [online]. Slavica litteraria 23, 2020, č. 1, s. 99-106 [cit. 29. 1. 2021]. Dostupné z: http://hdl.handle. net/11222.digilib/142646

NOVÁK 1915: NOVÁK, Arne. Praha barokní [online]. Praha: Mánes, 1915 [cit. 29. 1. 2021]. Dostupné z: https:// archive.org/details/prahabarok00nov

NOVÁK 1920: NOVÁK, Arne. La Prague baroque. Traduit du tchèque par Josefa Hrdinová. Praque: Aventinum, ŠtorchMarien, 1920.

NUMERISLAV: Numerislav [online]. DIM Science du texte et connaissances nouvelles [cit. 29. 1. 2021]. Dostupné z: http://www.dim-humanites-numeriques.fr/projets/numerislav/ PROVENIO DATABÁZE: Virtuální rekonstrukce knižních fondů. PROVENIO. Databáze vlastníků historických a moderních knižních sbírek a provenienčních záznamů v knihách. Knihovna Národního muzea [online]. Knihovna Národního muzea [cit. 29. 1. 2021]. Dostupné z: https:// www.provenio.net/provenience/

RES 2011: Revue des études slaves, tome 82, fascicule 1, 2011. André Mazon et les études slaves [online]. Sous la direction de Pierre Gonneau [cit. 29. 1. 2021]. Dostupné z: https:// www.persee.fr/issue/slave_0080-2557_2011_num_82_1

RES 2020: Revue des études slaves, tome 91, fascicule 1-2, 2020. Paris 1921: l'Institut d'études slaves, acteur de la slavistique [online]. Sous la direction de Sylvie Archaimbault et Pierre Gonneau [cit. 29. 1. 2021]. Dostupné z: https://journals.openedition.org/res $/ 3378$

ROMANISTIKA UP: Romanistika UP spolupracuje S pařížskou Sorbonnou na digitalizaci archivních fondů [online]. Univerzita Palackého v Olomouci [cit. 29. 1.
2021]. Dostupné z: https://www.upol.cz/nc/zpravy/zprava/clanek/romanistika-up-spolupracuje-s-parizskou-sorbonnou-na-digitalizaci-archivnich-fondu/

SEDLÁKOVÁ - POTƯČEK 2014: SEDLÁKOVÁ, Radomíra - POTU゚ČEK, Jakub. Přiběh Veletržního paláce. Praha: Národní galerie, 2014.

SKLENÁŘOVÁ 2013: SKLENÁŘOVÁ, Aneta. Život a dílo novinářky Miloslavy Sísové (1883-1947) [online]. Brno 2013. Bakalářská práce. Masarykova univerzita, Fakulta sociálních studií [cit. 29. 1. 2021]. Dostupné z: https://is.muni.cz/th/bno2h/Sklenarova_Aneta_BP.pdf STAVEBNICTVÍ A INTERIÉR 2015: Milan Kašpar a Alena Michálková.Architekt Jan Gillar(1904-1967) [online]. Stavebnictví a interiér 31. 3. 2015. STAVEBNICTVI3000. CZ [cit. 29. 1. 2021]. Dostupné z: https://www.stavebnictvi3000.cz/clanky/architekt-jan-gillar

TEIGE 1928-1929: TEIGE, Karel. Le Corbusier v Praze. Rozpravy Aventina 4, 1928-1929, s. 31-32.

VELFLÍK 1906: VELFLÍK, Albert Vojtěch. Dějiny technického učení $v$ Praze $s$ dějinným přehledem nejstaršich inženýrských škol, jakož i akademií a ústavi̊ v Rakousku, na nichž bylo vědám inženýrským nejdř́ve vyučováno. Pamětní spis na oslavu založení inženýrské školy v Praze pred 200 lety a stoletého trvání polytechnického ústavu Pražského. Díl 1. Od prvního vyučování inženýrským vědám v Rakousku 1686, až do zakončeni utraquistického období polytechnického ústavu v Království českém roku 1869 [online]. Praha: Česká vysoká škola technická, 1906, s. XXXXIII [cit. 29. 1. 2021]. Dostupné z:

http://www.digitalniknihovna.cz/mlp/view/ uuid:5d080580=0-e5e11-de-aa6f0030487-b43ea?pageuuid:955f0f50=19-df11-de82-ce0030487-b43ea\&fulltextPodhajsk\%C3\%BD

VEYRENC 1985: VEYRENC, Jacques. Historire de la slavistique française. In: HAMM, Josef-WYTRZENS, Günther (edd.). Beiträge zur Geschichte Slawistik in nichtslawischen Ländern. Wien: Verlag der Österreichischen Akademie der Wissenschaften (Schriften der Balkankommission Linguistische Abteilung, t. XXX), 1985, s. 245-303.

VLASIE 2013: VLASIE, Diana Elena. Invention du surréalisme et découverte critique du baroque. Thèse présentée comme exigence partielle du doctorat en études littéraires [online]. (Université du Québec a Montréal) et du doctorat en histoire et sémiologie du texte et de l'image (Paris Université Paris Diderot Paris 7). Février 2013 [cit. 29. 1. 2021]. Dostupné z: https://archipel.uqam.ca/5727/

ZATLOUKAL 2009: ZATLOUKAL, Jan (ed.). ČEP, Jan - PEŠKA, Vladimír. Milý Vladimíre... Milý Maestro... Vzájemná korespondence Jana Čepa a Vladimíra Pešky (1951-1966). Brno: CKD, 2009.

ZATLOUKAL 2014: ZATLOUKAL, Jan. L'exil de Jan Čep. Un écrivain tchèque en France. Paris: Institut d'études slaves, 2014. Travaux publiés par l'Institut d'études slaves, LXVII.

ZATLOUKAL 2016: ZATLOUKAL, Jan (ed.). Francouzští přátelé Jana Čepa. Brno: CKD, 2016.

ZDEŇKOVÁ 2017: ZDEŇKOVÁ, Marie. Znáte dobře Hostivař? Ze života $\mathrm{v}$ Horních Měcholupech a Hostivaři. 10. Část [online]. Hlasatel. Zpravodaj 
městské části Praha 15, 23, 2017, č. 11, s. 20-21 [cit. 29. 1. 2021]. Dostupné z: https://www.praha15.cz/assets/File. ashx? id org $=80115$ \&id dokumenty $=1107$

ZELENKA 2020: ZELENKA, Miloš. Le rôle de la slavistique française dans l'essor institutionnel et l'orientation intellectuelle de la slavistique tchèque après 1918 (André Mazon et Matija Murko dans les années 1920) [online]. In: Revue des études slaves, tome 91, fascicule 1-2, 2020 [cit. 29. 1. 2021]. Dostupné z: http://journals.openedition. org/res/3506

\author{
| Jaroslava Kašparová \\ Knihovna Národního muzea \\ oddělení rukopisů a starých tisků \\ Václavské náměstí 68 \\ 11000 Praha 1
}

